Article

\title{
Optimization of Ultrasound-Assisted Extraction of Bioactive Compounds from Acacia Seyal Gum Using Response Surface Methodology and Their Chemical Content Identification by Raman, FTIR, and GC-TOFMS
}

\author{
Tahani Maher ${ }^{1}\left(\mathbb{D}\right.$, Nassereldeen A. Kabbashi ${ }^{1, *} \mathbb{D}$, Mohamed E. S. Mirghani ${ }^{2} \mathbb{D}$, Md Z. Alam $^{1}$, \\ Djabir Daddiouaissa ${ }^{2} \mathbb{D}$, Ferid Abdulhafiz ${ }^{3} \mathbb{D}$, Mohd Farhan Hanif Reduan ${ }^{4}$, Jihad I. Omran ${ }^{5}$, \\ Mohammad Khairul Azhar Abdul Razab 6,*(D) and Arifullah Mohammed ${ }^{3, *(D)}$
}

1 Biotechnology Engineering Department, Kulliyyah of Engineering, International Islamic University Malaysia (IIUM), P.O. Box 10, Gombak, Kuala Lumpur 50728, Malaysia;

alawdat.tahani@live.iium.edu.my (T.M.); zahangir@iium.edu.my (M.Z.A.)

2 International Institute for Halal Research and Training (INHART), International Islamic University Malaysia (IIUM), Jalan Gombak, Kuala Lumpur 53100, Malaysia; elwathig@iium.edu.my (M.E.S.M.); daddiouaissa.djabir@live.iium.edu.my (D.D.)

check for

updates

Citation: Maher, T.; Kabbashi, N.A.; Mirghani, M.E.S.; Alam, M.Z.; Daddiouaissa, D.; Abdulhafiz, F.; Reduan, M.F.H.; Omran, J.I.; Abdul Razab, M.K.A.; Mohammed, A. Optimization of Ultrasound-Assisted Extraction of Bioactive Compounds from Acacia Seyal Gum Using

Response Surface Methodology and Their Chemical Content Identification by Raman, FTIR, and GC-TOFMS. Antioxidants 2021, 10, 1612. https:// doi.org/10.3390/antiox10101612

Academic Editors: Irina Ioannou and Cédric Peyrot

Received: 15 September 2021

Accepted: 8 October 2021

Published: 13 October 2021

Publisher's Note: MDPI stays neutral with regard to jurisdictional claims in published maps and institutional affiliations.

Copyright: (c) 2021 by the authors. Licensee MDPI, Basel, Switzerland. This article is an open access article distributed under the terms and conditions of the Creative Commons Attribution (CC BY) license (https:/ / creativecommons.org/licenses/by/ $4.0 /)$.
3 Faculty of Agro-Based Industry, Jeli Campus, Universiti Malaysia Kelantan, Jeli 17600, Malaysia; ferid.f18e006f@siswa.umk.edu.my

4 Department of Paraclinical Science, Faculty of Veterinary Medicine, Universiti Malaysia Kelantan, Pengkalan Chepa, Kota Bharu 16100, Malaysia; farhan.h@umk.edu.my

5 Biomedical Science Programme, Faculty of Health Sciences, Universiti Kebangsaan Malaysia, Jalan Raja Muda Abdul Aziz, Kuala Lumpur 50300, Malaysia; p94173@siswa.ukm.edu.my

6 School of Health Sciences, Health Campus, Universiti Sains Malaysia, Kubang Kerian 16150, Malaysia

* Correspondence: nasreldin@iium.edu.my (N.A.K.); khairul.azhar@usm.my (M.K.A.A.R.); aurifullah@umk.edu.my (A.M.)

Abstract: Acacia Seyal gum (ASG), also known as gum Arabic, is an antioxidant-rich soluble fiber. ASG has been reported to have many biological activities, including anticancer, antidiabetic, antiulcer, and immunomodulatory activity. Extraction of bioactive compounds from ASG is commonly performed using conventional extraction methods. However, these techniques have certain limitation in terms of extraction time, energy, and solvent requirements. Ultrasound-assisted extraction (UAE) could be used as an alternative technique to extract bioactive compounds in less time, at low temperature, and with less energy and solvent requirements. In this study, the UAE extraction of ASG was optimized using response surface methodology (RSM). A face-centered central composite design (FCCCD) was used to monitor the effect of different independent factors of ultrasound operation (sonication time, temperature, and solvent ratio) on ASG extraction yield. In addition, screening and characterization of phytochemicals in $60 \%$ ethanol ASG extract was carried out using Raman microscopy, Fourier transform infrared spectroscopy (FTIR), and gas chromatography time-of-flight mass spectroscopy (GC-TOFMS) analysis. The results indicated that, under optimal conditions (extraction time $45 \mathrm{~min}$, extraction temperature $40{ }^{\circ} \mathrm{C}$, and solid-liquid ratio of $1: 25 \mathrm{~g} / \mathrm{mL}$ ), the yield of ASG was $75.87 \% \pm 0.10$. This yield was reasonably close to the predicted yield of $75.39 \%$ suggested by the design of experiment. The ANOVA revealed that the model was highly significant due to the low probability value $(p<0.0001)$. Raman spectrum fingerprint detected polysaccharides, such as galactose and glucose, and protein like lysine and proline, while FTIR spectrum revealed the presence of functional groups peaks value of alkanes, aldehydes, aliphatic amines, and phenol. GCTOFMS spectroscopic detected the presence of strong D-galactopyranose, carotenoid, and lycopene antioxidant compounds. In conclusion, this study demonstrated that the UAE technique is an efficient method to achieve a high yield of ASG extracts. The selected model is adequate to optimize the extraction of several chemical compounds reported in this study. 
Keywords: Acacia Seyal gum; gum Arabic; ultrasound-assisted extraction; response surface methodology; Raman spectroscopy; FTIR spectra; GC-TOFMS

\section{Introduction}

Over the last few years, the use of natural compounds for the prevention and treatment of various diseases is becoming increasingly popular and they have shown significant results in the treatment of cancer, Alzheimer, metabolic disorders, inflammations, arthritis, etc. [1]. Beside its therapeutic values, the utilization of natural compounds from various sources has been increased in the food and pharmaceutical industries [2]. As a source of natural health-benefitting compounds, ASG has been used in folk medicine globally. ASG is a dried secretion from trees of Acacia Senegal and Acacia Seyal. These trees are primarily grown in sub-Saharan African countries, particularly Sudan, Chad, Uganda, and Eritrea. ASG provides a rich source of antioxidant and is reported to have many biological activities including anticancer, anti-inflammatory, hypoglycemic, antidiabetic, antioxidant, and antiulcer activity [3,4]. The biological activity of ASG is associated with its high flavonoid and polyphenolic components $[5,6]$. Furthermore, it is reported to have abundant terpenoids, tannins, lignans, alkaloids, coumarins, and quinones $[7,8]$.

Drug development is highly dependent on the natural ingredients derived from medicinal plants. However, these substances are usually found in plants in a small quantity. Therefore, developing an effective and selective techniques for extracting and isolating such bioactive natural compounds is greatly important.

Conventional extraction procedures, such as percolation, maceration, and reflux, often utilize organic solvents and need a significant volume of solvents and a long extraction period. Previous studies demonstrate that the conventional methods employed for extracting bioactive compounds from ASG are time consuming and have low yields with low amounts of bioactive compound [3,9].

To overcome these problems, novel and environment-friendly (green chemistry) extraction technologies have been suggested including pressurized liquid extraction (PLE), ultrasound-assisted extraction (UAE), microwave-assisted extraction (MAE), and supercritical fluid extraction (SFC) [10]. UAE is simpler and faster than other extraction methods. UAE consider a sustainable and economically feasible technology suitable for the extraction heat-sensitive compounds. Moreover, it reduces energy usage while producing safe and greater yield of product [11,12]. UAE is appropriate for the extraction of thermolabile and unstable compounds as well as the extraction of a variety of natural plant metabolites [11].

UAE extraction efficiency is affected by the properties of the extraction solvent, the particle size of the raw materials, the solvent-to-solid ratio, the extraction temperature, and the extraction time. Hence, to achieve maximum extraction yield, optimization of extraction techniques by response surface analysis is required to study the influence of different independent variables such as solid-liquid ratio, extraction temperature, extraction time. RSM is an effective optimizing method that requires a reduced number of experimental runs to assess multiple parameters and their interactions [13,14].

Medicinal plants are well known to have chemically diverse compounds produced in very low quantities and are prone to variation due to environmental and other factors [15]. As the use of medicinal plants or natural products continues to gain huge popularity globally, there is a dire need for the detail biochemical-content studies [16,17]. Therefore, advanced analytical techniques are appropriate for the separation, identification, and quantification of compounds. Several advanced analytical technologies have been used in recent years, including Raman spectroscopy, Fourier transform infrared spectroscopy (FTIR), and gas chromatography time-of-flight mass spectroscopy (GC-TOFMS). Raman spectroscopy is increasingly being used to examine medicinal plants to identify and detect natural organic materials and efficiently and precisely identify the chemical components of herbal medications [18]. Raman spectroscopy uses benefits from its non-destructive 
nature. It is a non-invasive method and can be applied to any sample's physical state with no sample size restriction [19]. The FTIR technique is used to detect the presence and characterize unknown functional groups present in a plant sample [20]. On the other hand, GC-TOFMS is used to detect the occurrence of bioactive compounds quantitatively and qualitatively. It also detects compounds that are present at very low concentrations and expands the opportunity to explore new bioactive compounds [21].

In this study, 60\% ethanol was used as the extraction solvent based on preliminary study results that showed that $60 \%$ ethanol produced a high extraction yield. In addition, the polysaccharides extracted from ASG using this ethanol concentration showed the highest bioactivity. Hence, we aim to extract compounds with useful biological activity from ASG to be used later for further research. The objective of this study was to employ response surface methodology to investigate the effect of different UAE extraction process variables (extraction temperature, ultrasonic extraction time, and solid-solvent ratio) on yields of extracts. In addition, the phytochemical compounds present in $60 \%$ ethanol extract were identified using Raman spectra, FTIR, and GC-TOFMS techniques.

\section{Materials and Methods}

\subsection{Raw Material and Reagents}

ASG exudate was purchased from the local farmers market in El-Obeid, State of North Kurdufan, Sudan. The collection of gum by the farmers took place during the dry season from November to May 2017. The sample was then verified by experts from the Sudanese Ministry of Forestry and Agriculture. The impurities and pieces of bark were removed by hand and then the gum was crushed into fine powder by using mortar and pestle and then sieved using Fisher brand USA standard testing sieve (Fisher Scientific, Waltham, MA, USA) with $1.40 \mathrm{~mm}$ mesh size. The final ASG powder was packed in polyethylene zipped bags $(12 \mathrm{~cm} \times 12 \mathrm{~cm})$ and stored at $4{ }^{\circ} \mathrm{C}$ until further analysis. Sampling was performed only one time. Ethanol used in the extraction was of analytical grades and purchased from HmbG chemical (HmbG GmbH, Hamburg, Germany).

\subsection{Plant Sample Extraction}

Extractions were performed following the method of Adwan et al. [1] and Esmaeili et al. [22] with some modification using an ultrasonic bath, model DSA100-SK2 (Fuzhou Desen Precision Instruments Co., Ltd., Fujian, China). The UAE experiments were carried out at different ranges of solid-to-liquid ratios (1:15-1:25 g/mL), sonication temperatures $\left(30-50{ }^{\circ} \mathrm{C}\right)$, and sonication times (30-60 min) following the designated experimental design.

The gum powder $(3 \mathrm{~g})$ was dissolved in $30 \mathrm{~mL}$ of $60 \%$ ethanol $(v / v)$ (ethanol was diluted with distilled water), and then it was covered with aluminum foil and extracted with a $40 \mathrm{kHz}$ sonication power in an ultrasonic bath under the specified conditions. Preliminary investigations and other relevant research were used to identify the independent variables and their fluctuation ranges [23]. The experiments were carried out in which the time, temperature, and solid-to-liquid ratios were chosen as per the values suggested by the RSM design, and the extracts were filtered and centrifuged at 15,000 $\mathrm{g}$ for $10 \mathrm{~min}$. The solvent was discarded using a rotary vacuum evaporator (Büchi rotavapor, Buchi, Flawil, Switzerland) at $40^{\circ} \mathrm{C}$, followed by freeze drying for $72 \mathrm{~h}$ in a freeze dryer (Scanvac Cool Safe 55-4, Scanvac, Denmark) The extraction yield value of ASG was calculated after each experiment. The dried extracts were kept at $-20^{\circ} \mathrm{C}$ for further analysis [12].

\subsection{Ultrasound-Assisted Extraction (UAE) Optimization}

The design of the experiment was applied to evaluate and observe the impacts of extraction parameters, extraction method on ASG extraction yield (\%), and the chemical content of bioactive compounds obtained. The preliminary experiments showed several factors affecting ASG extraction in addition to the type of the extracting solvent, such as the extraction temperature, time, and solid-liquid ratio [24]. All the experiments were 
performed in triplicates and the results expressed as mean values \pm standard error. The extraction yield (\%) was defined as the response ( $\mathrm{Y})$.

\subsection{Experimental Design}

The RSM was used to design the experiments based on the face-centered central composite design (FCCCD), which included both axial and central points. The total number of samples examined under RSM were 20 (20 experimental runs), and each run was subjected to triplicate analysis. The optimal conditions were determined using analysis of variance (ANOVA), contour plots, and residual plots. Ultrasonication time, temperature, and solid-liquid ratio were independent factors tested in 20 experimental runs to get the optimal conditions for UAE of ASG. The yield was chosen as the design experiment's response $(\mathrm{Y})$. For the factor assessments, the independent variables were adjusted to ranges between -1 and +1 . The variables' levels in the RSM design were studied at two levels, low $(-1)$ and high $(+1)$, as shown in Table 1. The RSM statistical analysis was employed using Design Expert Software v12.0.0 (Stat-Ease Inc., Minneapolis, MN, USA).

The parameters employed were extraction time (30-60 min), extraction temperature $\left(30-50^{\circ} \mathrm{C}\right)$, and solid-liquid ratio (15-25). The extraction yield of gum was calculated using the final dry weight of extracted gum relative to the original gum powder [25]. Equation (1) was used to determine the extraction yield:

$$
\text { Extraction yield }(\%)=\frac{\text { Weight of the extract after extraction }(\mathrm{g})}{\text { Weight of the original sample }(\mathrm{g})} \times 100
$$

Table 1. Experimental design and levels of independent process variables.

\begin{tabular}{cccc}
\hline Symbol & Independent Variables & Low Level & High Level \\
\hline A & Extraction Time $(\mathrm{min})$ & 30 & 60 \\
B & Extraction Temp $\left({ }^{\circ} \mathrm{C}\right)$ & 30 & 50 \\
C & Solid-Liquid Ratio $(\mathrm{g} / \mathrm{mL})$ & 15 & 25 \\
\hline
\end{tabular}

Several studies confirmed the influence of the extraction method and type of solvent on the extract yield, phytochemical content, and biological activity $[11,23]$. This study used the phytochemical screening and chemical characterization of secondary metabolites in ASG extract using ultrasound-assisted extraction with $60 \%$ ethanol to explore the bioactive metabolites and their structures present in the sample.

\subsection{Raman Spectroscopy Spectra}

The ASG-optimized powder was assessed by Raman analysis in the INHART laboratory, International Islamic University Malaysia, Jalan Gombak, 53100, Selangor, Malaysia using a Renishaw System-1000 spectrometer from Wotton-Under-Edge, UK, paired with a diode laser at a wavelength of $785 \mathrm{~nm}$ and a $50 \mathrm{~mW}$ output power as an excitation source. Using a series of neutral density filters, the laser intensity on the sample may be adjusted up to around $5 \mathrm{~mW}$. While considering possible sample inhomogeneity, a $50 \times$ objective lens was used to concentrate the light on the sample. The spectrum was captured at a magnification of $20 \times$, with an extended Raman range of $100-3200 \mathrm{~cm}^{-1}$, an exposure time of $10 \mathrm{~s}$, and laser power of $1 \% 785 \mathrm{~nm}$ edge. The spectrum was processed with the computer peak acquisition and Microsoft Excel software.

\subsection{FTIR Spectroscopy}

Spectra were measured with an FTIR spectrometer (Nexus 670 Fourier transform infrared spectrometer, (Thermo Scientific, Waltham, MA, USA) with a PC-based softwarecontrolled instrument for operation and data processing. The powdered samples were put onto the tiny crystal area after it was cleaned, and the pressure arm was placed over it. The spectrum was obtained after applying force to the sample and pressing it onto the diamond surface. Spectra were recorded at $400-4000 \mathrm{~cm}^{-1}$ scanning range and $1 \mathrm{~cm}^{-1}$ 
resolution. The average spectra were evaluated. For comparison between different spectra, multiple-point baseline correction and spectra normalization were done. The samples were examined in triplicates. The spectral data were compared to the previous research studies on FTIR of various chemical compounds to identify the functional groups that present in the sample.

\subsection{Gas Chromatography Time-Of-Flight Mass Spectrometry (GC-TOF-MS) Analysis}

The required quantity of ethanolic ASG crude extract was filtered using a nylon syringe filter $(0.45 \mu \mathrm{m})$. In the split mode $(10: 1), 2 \mu \mathrm{L}$ of plant extract was administered before being subjected to GC-TOFMS analysis. The analysis was performed by using Thermo GC ultra Clarus 500 system and gas chromatograph integrated to a mass spectrometer (GC-TOFMS) supplied with an Elite-I-fused RMS 5 silica capillary column composed of 100\% Dimethylpolysiloxane as described by Daddiouaissa et al. [26]. As a carrier, helium gas was utilized at a constant flow rate of $1 \mathrm{~mL} / \mathrm{min}$, with a sample injection volume of $1 \mu \mathrm{L}$ and a sample split ratio of 10:1. The injector and ion source temperatures were set at $250{ }^{\circ} \mathrm{C}$ and $260{ }^{\circ} \mathrm{C}$, respectively. The oven temperature was set to rise from $110{ }^{\circ} \mathrm{C}$ to $260{ }^{\circ} \mathrm{C}$ at a rate of $5{ }^{\circ} \mathrm{C} / \mathrm{min}$, with a $3 \mathrm{~min}$ isothermal ending at $260{ }^{\circ} \mathrm{C}$. An electron ionization device with a $70 \mathrm{eV}$ ionizing energy was utilized to detect mass spectra, with a mass scanning range of $10-400 \mathrm{~m} / \mathrm{z}$. For handling mass spectra and chromatograms, Turbo mass software was used. The GC analysis was done in triplicate.

\section{Component Identification}

The National Institute of Standards and Technology (NIST) database was used to identify components and interpret the mass spectrum of GC-TOFMS (https:/ / www.nist. gov/srd/nist-standard-reference-database-1a-v14) (Accessed on 1 September 2021). Based on the spectra recorded in the NIST and Wiley libraries, unknown components were compared to known components.

\subsection{Statistical Analysis}

RSM statistical analysis was employed using Design Expert Software v12.0.0 (StatEase Inc., Minneapolis, MN, USA). All experimental results obtained were expressed as means $\pm \mathrm{SD}$, data were analyzed by analysis of variance $(p<0.05)$, and the means were separated by Duncan's multiple range tests. All analyses were performed in triplicates.

\section{Results and Discussion}

\subsection{Optimization of Acacia Seyal Gum Extraction Parameters by RSM}

The FCCCD under RSM was employed to investigate the optimal parameters of the three variables (extraction time, extraction temperature, and solid-liquid ratio) to maximize the extraction yield. The experimental results and the predicted yield obtained from the regression equations are presented in Table 2 . The highest order polynomials were used to choose the models. The resulting data were fitted with the quadratic model as suggested by the software, and each experimental run showed the interaction between each factor level where the response was the extraction yield (\%).

ASG had a wide range of yields from $64 \%$ to $76 \%$, and the maximum yield was found at the extraction time of $45 \mathrm{~min}$, an extraction temperature of $40^{\circ} \mathrm{C}$, and the solid-liquid ratio of $25 \mathrm{~g} / \mathrm{mL}$. The conditions of the optimal process were analyzed to obtain high extraction yields. These results demonstrated that the yield (\%) was maximal with the mid value of extraction temperature (B), mid values of extraction time (A)m and high values of solid-liquid ratio $(\mathrm{C})$. On the other hand, it was found to be minimal at the high value of extraction time (A), high values of extraction temperature (B), and low values of solid-to-liquid ratio (C). The importance of A and B were found to significantly affect the extraction efficiency (Table 3). 
Table 2. FCCCD experimental design and the response.

\begin{tabular}{|c|c|c|c|c|c|}
\hline \multicolumn{6}{|c|}{ Extraction Condition Yield (\%) } \\
\hline Run & $\begin{array}{c}\text { A: Extraction Time } \\
\text { (min) }\end{array}$ & $\begin{array}{l}\text { B: Extraction Temp } \\
\left({ }^{\circ} \mathrm{C}\right)\end{array}$ & $\begin{array}{c}\text { C: Solid-Liquid Ratio } \\
\text { (g/mL) }\end{array}$ & Actual & Predicted \\
\hline 1 & 30 & 30 & 25 & $65 \pm 0.02$ & 65.28 \\
\hline 2 & 30 & 40 & 20 & $70 \pm 0.01$ & 69.14 \\
\hline 3 & 45 & 30 & 20 & $70 \pm 0.03$ & 70.8 \\
\hline 4 & 30 & 30 & 15 & $65 \pm 0.27$ & 64.60 \\
\hline 5 & 60 & 30 & 15 & $64 \pm 0.15$ & 63.54 \\
\hline 6 & 60 & 30 & 25 & $65.3 \pm 0.1$ & 64.89 \\
\hline 7 & 45 & 40 & 20 & $76 \pm 0.08$ & 75.39 \\
\hline 8 & 60 & 50 & 15 & $66 \pm 0.06$ & 65.66 \\
\hline 9 & 45 & 40 & 20 & $76 \pm 0.41$ & 75.39 \\
\hline 10 & 45 & 40 & 15 & $74 \pm 0.09$ & 74.60 \\
\hline 11 & 30 & 50 & 25 & $65 \pm 0.09$ & 65.39 \\
\hline 12 & 60 & 50 & 25 & $67 \pm 0.54$ & 67.34 \\
\hline 13 & 45 & 40 & 20 & $75 \pm 0.08$ & 75.40 \\
\hline 14 & 45 & 40 & 20 & $76.3 \pm 0.01$ & 75.40 \\
\hline 15 & 45 & 40 & 25 & $76.6 \pm 0.05$ & 75.97 \\
\hline 16 & 45 & 40 & 20 & $74 \pm 0.08$ & 75.39 \\
\hline 17 & 45 & 50 & 20 & $73 \pm 0.51$ & 71.92 \\
\hline 18 & 45 & 40 & 20 & $75 \pm 0.53$ & 74.60 \\
\hline 19 & 30 & 50 & 15 & $64 \pm 0.12$ & 64.30 \\
\hline 20 & 60 & 40 & 20 & $69 \pm 0.2$ & 69.60 \\
\hline
\end{tabular}

Table 3. ANOVA for a fitted quadratic model of extraction conditions with yield (\%).

\begin{tabular}{cccccc}
\hline Source & Sum of Squares & Degree of Freedom & Mean Square & F-Value & $p$-Value \\
\hline Model & 431.23 & 9 & 47.91 & 53.2 & $<0.0001$ \\
A-Time & 0.54 & 1 & 0.54 & 0.6 & 0.0045 \\
B-Temp & 3.21 & 1 & 3.21 & 3.57 & 0.0088 \\
C-S/L & 3.59 & 1 & 3.59 & 3.98 & 0.07 \\
AB & 2.73 & 1 & 2.73 & 3.03 & 0.11 \\
AC & 0.22 & 1 & 0.22 & 0.25 & 0.63 \\
BC & 0.06 & 1 & 0.06 & 0.06 & 0.81 \\
A $^{2}$ & 99.96 & 1 & 99.96 & 111 & $<0.0001$ \\
B $^{2}$ & 44.64 & 1 & 44.64 & 49.57 & $<0.0001$ \\
Residual & 0.11 & 1 & 0.11 & 0.12 & 0.74 \\
Lack of Fit & 9.01 & 10 & 0.9006 & & 0.38 \\
Pure Error & 5.14 & 5 & 1.03 & 1.33 & not significant \\
Cor Total & 3.86 & 5 & 0.77 & & \\
\hline
\end{tabular}

\subsection{Statistical Data Analysis}

Based on a $95 \%$ confidence interval, the analysis of variance was used to verify the significant impacts of process variables on the ASG yield. The ANOVA results show that the interactive parameters $\mathrm{A}, \mathrm{B}, \mathrm{A}^{2}$, and $\mathrm{B}^{2}$ were the significant parameters, while the linear coefficient $C$ and the interactions terms $A B, A C$, and $B C$, as well as the quadratic coefficient $C^{2}$ were insignificant (Table 3 ). However, these interaction terms were taken into consideration as they maintain the current model. In addition, the lack of fit (0.38) is considered not significant $(p>0.05)$, which means that the model fits well.

The ANOVA model analysis for the RSM gave the quadratic results shown in Table 3. According to the resulting analyses, the impact of each variable on the experimental response showed good prediction, where the predicted $R^{2}$ of 0.89 is closer to the adjusted $\mathrm{R}^{2}$ of 0.96 with a difference of less than 0.2 . Thus, the model is better fitted when the coefficient of determination $R^{2}$ value is closer to one. As a result, $R^{2}$ values showed that the regression model for each response accurately represented the system's actual behavior. Based on regression coefficient values, extraction time A and extraction temperature B showed a positive effect, and the positive regression coefficient indicates that increasing the extraction time would improve the ASG extraction yield. The negative regression coefficient 
for the solid-liquid ratio means that its increase would decrease the ASG extraction yield. The $A B$ and $B$ regression coefficients were also positive. On the other hand, a low coefficient of variance $(\mathrm{CV} \%)$ of 1.35 for all the responses showed an excellent accuracy and reliability of the model. Commonly, if its CV is less than $10 \%$, the model is considered reasonably reproducible [27]. Adequate precision measures the signal-to-noise ratio, where values that are more than 4 are considered desirable. The adequate precision of 18.26 of the extraction yields indicates an adequate signal, and the model generated can be used to navigate the design space.

The model equations for the response shows the relationship between extraction time, temperature, and solid-liquid ratio and yield (Equation (2)).

$$
\begin{gathered}
\mathrm{Y}=-41.4910+2.2271 \times \mathrm{A}+3.0713 \times \mathrm{B}+0.2716 \times \mathrm{C}+0.00389 \times \mathrm{A} \times \mathrm{B}+0.00221 \times \\
\mathrm{A} \times \mathrm{C}+0.001675 \times \mathrm{B} \times \mathrm{C}-0.00268 \times \mathrm{A}^{2}-0.0403 \times \mathrm{B}^{2}-0.08 \times \mathrm{C}^{2}
\end{gathered}
$$

where $\mathrm{Y}$ is the predicted responses (yield \%), and $\mathrm{A}, \mathrm{B}$, and $\mathrm{C}$ are the coded values for the independent variables, in which $\mathrm{A}$ is time, $\mathrm{B}$ is temperature, and $\mathrm{C}$ is the solid-liquid ratio, respectively.

The experimental error with a $95 \%$ confidence interval (CI) for the means was determined based on the differences between observed and predicted responses in order to evaluate the variable effects and their interactions (Table 4).

\begin{tabular}{|c|c|c|c|c|c|c|c|c|c|}
\hline Response & $\begin{array}{l}\text { Predicted } \\
\text { Mean }\end{array}$ & $\begin{array}{l}\text { Predicted } \\
\text { Median }\end{array}$ & Observed & Std Dev & SE. Mean & $\begin{array}{l}\text { 95\%CI Low } \\
\text { for Mean }\end{array}$ & $\begin{array}{l}\text { 95\%CI High } \\
\text { for Mean }\end{array}$ & $\begin{array}{l}\text { 95\%TI Low for } \\
\text { 99\% Pop }\end{array}$ & $\begin{array}{l}\text { 95\%TI High } \\
\text { for } 99 \% \text { Pop }\end{array}$ \\
\hline yield & 75.88 & 75.88 & 74.89 & 0.94 & 0.66 & 74.39 & 77.35 & 70.78 & 80.97 \\
\hline
\end{tabular}

Table 4. Confidence and prediction interval ANOVA analysis results.

RSM was used to create various forms of 3D response surface contour plots to show the anticipated model equation and, therefore, the interaction between the different factors and response. These graphs demonstrated the effect of extraction time, solid-liquid ratio, and temperature on the percentage of the extraction yield.

\subsection{The Interaction Response Effects}

As can be observed, the optimal conditions were determined by maximizing the desirability of the responses using Design Expert Software, where all three factors, including sonication time and temperature, as well as the solvent-solid ratio, had a considerable effect on ASG extraction efficiency $(p<0.05)$. Figure 1 shows the synchronized effect of sonication time and temperature on the yield amount of ASG extracted by $60 \%$ ethanol. According to the results, the time has a significant impact on extraction yield, so that with increasing the time from 30 to $45 \mathrm{~min}$, the extraction yield went upward, and the maximum value was obtained in $45 \mathrm{~min}$, but with increasing time to $60 \mathrm{~min}$, the yield again decreased, which relates to the fact that the quadratic effect can be seen in the diagram. The extraction time was substantially impacted, as seen by the three-dimensional (3D) surface plots (Figure 1). The extraction yield of ASG extract improved with the rise of extraction time and the extraction temperature influence, taking into consideration that the longer heating period resulted in a lower extraction yield. 


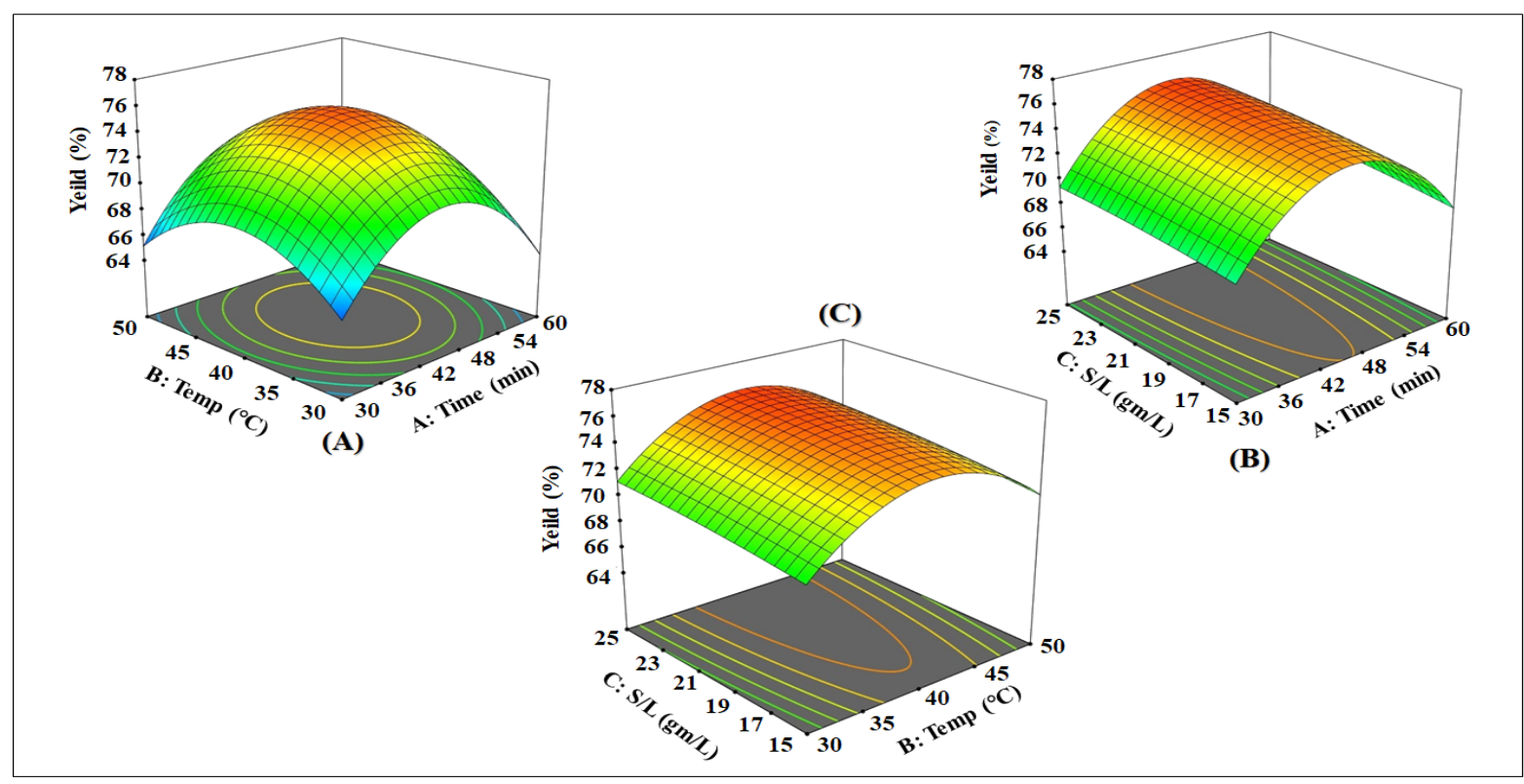

Figure 1. 3D plots representing the effects of (A) extraction time and temperature, (B) time and solid-liquid ratio, and (C) extraction temperature and solid-liquid ratio.

Responses were optimized at the same time, and the model was used to find the best conditions. The optimal conditions for ASG extraction by UAE suggested by the model to gain high yields were specified as follows: a 45 min extraction time, a $40{ }^{\circ} \mathrm{C}$ temperature, and a $1: 25 \mathrm{~g} / \mathrm{mL}$ solid-liquid ratio to reach the optimum yield of $75.88 \pm 0.94 \%$. These settings were chosen to maximize the yield, with $\mathrm{D}=0.9$ having the greatest overall desirability. Figure 1 depicts the effects of the experimental levels of tested variables on the response. The contour plots came in a variety of forms, indicating various interactions between factors. Figure 1A shows the effect of extraction time and temperature and their influence on the percentage of extraction yield. The yield of ASG extract improved when the extraction time increased. The ultrasound waves require a certain time to stimulate the cellwall interference and then release the extract. A similar effect of extraction temperature on the yield of ASG extract was observed. Results showed that when extraction temperature increased, the solubility of ASG also increased, which also improves the extraction yield. The yield of ASG extract also increased because of other reasons like higher solvation, increasing material porosity, and mass transfer, as confirmed by Chan et al. [28]. The impact of extraction temperature on ASG yield and its phytochemical content confirmed by a previous study conducted by Elnour et al. [29] showed that increases in extraction yield in the content of phenolic components of samples resulted from increased extraction temperature. However, the results were that, with increasing temperature from 30 to $40{ }^{\circ} \mathrm{C}$, the extraction yield increased, and there were increases in yield with increasing sonication temperature due to the mass transfer produced by the increase in ASG solubility and the decrease in solvent viscosity. Other research also detailed the important effect of temperature during extraction on the mass transfer of water-soluble polysaccharides, and the increase in extraction efficiency of polysaccharides in the extract while during increasing the temperature up to $60^{\circ} \mathrm{C}$, where the quantity of extracted ASG decreased (Figure 1).

The extraction yield was maximal at a temperature of $40.83{ }^{\circ} \mathrm{C}$ and decreased at further increases of temperature. However, the over increase in the temperature led to a decrease in the extraction yield since the extraction temperature exceeded the optimum temperature, as in the case of over $60^{\circ} \mathrm{C}$, due to oxidative degradation and the decrease in solvent ability to dissolve the bioactive compounds, where more than $50 \%$ (vol) of the solvent was evaporated. In fact, the present findings are analogous to the results reported 
by Bi et al. [30]. For this reason, a milder heating condition is considered appropriate for the extraction, where the optimum condition was taken at $40^{\circ} \mathrm{C}$.

Figure $1 \mathrm{~B}$ displays the response surface plot of extraction time and solid-liquid ratio and their interactions on the percentage of the extraction yield. Extraction time is important parameter in solid-liquid extraction because it affects the solubility and mass transfer of bioactive compounds. Furthermore, as shown in Figure 1B, the yield raised with an increase in extraction time up to $45 \mathrm{~min}$, and then decreased slightly. Prolonged extraction time increases the possibility of oxidation, epimerization, and degradation of bioactive compounds. These results explain the critical role of extraction time in minimizing extraction process costs.

Similar interactions of the extraction temperature and solid-liquid ratio were observed in Figure 1C in the UAE of ASG. Results showed that when extraction temperature increased, the solubility of ASG also increased then decreased. Moreover, the yield was not significantly affected when the sample-to-solvent ratio increased from $1: 15$ to $1: 25 \mathrm{~g} / \mathrm{mL}$; therefore, it does not affect minimizing or maximizing the yield response. The solid-liquid ratio's effect on optimization was studied to increase the extraction efficiency, as well as decreasing production cost and solvent usage. A solid-liquid ratio of $1: 25 \mathrm{~g} / \mathrm{mL}$ was found to give the best results to achieve the optimum extraction yield of $75.87 \%$. To optimize ASG extraction yield, the model equation was utilized to forecast the best extraction conditions. The model's recommended optimal conditions to gain high yields were specified as follows: a temperature of $40.83{ }^{\circ} \mathrm{C}$ with a solid-liquid ratio of $1: 25 \mathrm{~g} / \mathrm{mL}$ and a $45.56 \mathrm{~min}$ extraction time. To compare the predicted result with the measured values, triple experiments $(n=3)$ were conducted under optimal circumstances to compare the anticipated result with the measured values.

\subsection{Validation of the Optimized Parameter}

Additional extractions were carried out to validate the generated model and to confirm the best results. The optimized condition was obtained at a temperature of $40^{\circ} \mathrm{C}$, a solidliquid ratio of $1: 25 \mathrm{~g} / \mathrm{mL}$, and an extraction time of $45 \mathrm{~min}$. The experimental values were compared with predicted values based on $\mathrm{CV} \%$ to determine the validity of the model.

Validation tests revealed that the average yield was $74.89 \pm 0.32 \%$. These values are close to the predicted yield of $75.87 \%$, indicating that the model is suitable for optimization. The greatest extraction yield of ASG was obtained in UAE extraction with a lower ratio of solvent, greater time, and an appropriate temperature. This study approved the results of another study [31], which confirmed that the yield increased once the time for extraction increased; however, this was under a controlled temperature. The fact that these findings were so closely related proved that the response model was accurate in representing the predicted optimization. It also implies that when/by utilizing UAE, the models can accurately estimate ASG extraction yield. The desirability function was also used to predict one set of optimum conditions for three response variables.

\subsection{Raman Spectroscopy}

The ASG Raman spectrum for ethanol extract is nearly the same compared to the earlier raw gum spectrum. TheRaman spectra of ASG is presented in Table 5. The optimized extracts fingerprint spectra were obtained with the Raman spectrum, in which the ethanol gum ASG sample had three primary peaks of 1330 and $825 \mathrm{~cm}^{-1}$. The ASG spectra indicated bands at around $1715 \mathrm{~cm}^{-1}$. However, the spectrum ASG indicated two bands of 2905 and $2577 \mathrm{~cm}^{-1}$ of diameter (Figure 2). In this research, the spectra of the extreme ribbons were about $2700 \mathrm{~cm}^{-1}$, which was ascribed to the $\mathrm{N}-\mathrm{H}$ and $\mathrm{C}-\mathrm{H}$ for amin and alkyl, respectively, where the results coincide with Freire et al. [32]. The sharp band is considered a hallmark frequency for the SH and SS groups at $2577 \mathrm{~cm}^{-1}$ [33]. At $1333 \mathrm{~cm}^{-1}$ of total waves, 1 Raman galactose and glucose band was visible, respectively, as ASG consists primarily of monosaccharide arabinose and galactose units. De Pinto et al. [34] previously reported the same findings in previous investigations and found that acacia gums comprise 
D-galactose, L-rhamnose, L-parabiotic acids, and two uronic acids, glucuronic acids, and 4-O-methyl-glucuronic acids. The vibration of deformation of C-C- $\mathrm{H}, \mathrm{C}-\mathrm{H}_{2}$ was related to the band seen at $1340 \mathrm{~cm}^{-1}$ [35]. The ring deformation was allocated to the sharp band at $1373 \mathrm{~cm}^{-1}$. At 1032 and $1083 \mathrm{~cm}^{-1}$, the peak was predominantly attributed to the bending vibration of $\mathrm{CN}$ bonds in proteins and amino acids, and the vibration of $\mathrm{C}-\mathrm{H}$ and C-O-H in carbohydrates contributed little. The $800-900 \mathrm{~cm}^{-1}$ portion of the reference values for Raman originated in the stretching of a functional C-C skeleton (n-alkane) group, which is a hydrocarbon composed solely of C-C individual bonds and has a C-O-C, C-O-H glycosidic ring stretching sugars [36,37]. In the meantime, sugar bands range between 800 and $1100 \mathrm{~cm}^{-1}$ as well as at $1400 \mathrm{~cm}^{-1}$ [38]. In addition, the $800 \mathrm{~cm}^{-1}$ bands were allocated to the $\mathrm{C}-\mathrm{H}, \mathrm{C}-\mathrm{O}-\mathrm{H}$, and $\mathrm{CH}_{2}$ curves [39]. A combination of the characteristics of $\mathrm{CH}_{2}$ and $\mathrm{COO}$ group vibrations formed the absorption bands at $1500 \mathrm{~cm}^{-1}, 1476 \mathrm{~cm}^{-1}$, and $1260 \mathrm{~cm}^{-1}$, and a single spectral region was attributed to flavanol and organic acid. The results were agreed with by $[40,41]$, who described the quick detection of antioxidant phenolic chemicals.

Table 5. Functional groups assigned peaks of Acacia Seyal gum using Raman spectroscopy.

\begin{tabular}{ccc}
\hline Wave Number $\mathbf{c m}^{-1}$ & Approximate Assignment & Functional Group \\
\hline 3200 & $\mathrm{O}-\mathrm{H}$ & phenols \\
$>2700$ & $\mathrm{~N}-\mathrm{H}$, and C-H stretching modes & Amin, Alkyl \\
2577 & $\mathrm{~S}-\mathrm{H}, \mathrm{S}-\mathrm{S}$ & Sulfhydryl \\
$1500-1700$ & $\mathrm{C}=\mathrm{O}$ and $\mathrm{C}=\mathrm{N}$ stretch & Alkyl ketone \\
$1500-1550$ & $\mathrm{~N}-\mathrm{O}$ stretching & Nitro compound \\
$900-1200$ & $\mathrm{C}-\mathrm{C}$ stretching, $\mathrm{CH}_{3}, \mathrm{CH}_{2}, \mathrm{C}=\mathrm{O}$ & Alkane \\
1461 & $\mathrm{C}-\mathrm{H}$ bending & Methylene group \\
1340 & $\mathrm{C}-\mathrm{C}-\mathrm{H}_{1} \mathrm{C}-\mathrm{H}_{2}$ bending & Alkane. \\
1333 & $\mathrm{CH} \mathrm{H}_{2}$ vibrations & Monosaccharide galactose, glucos \\
1326,1261 & $\mathrm{C}-\mathrm{O}$ stretching & Alkyl Ester \\
1301 & $\mathrm{CH} \mathrm{H}_{2}$ & Carotenoids \\
1078 & $\mathrm{C}-\mathrm{O}, \mathrm{C}-\mathrm{C}, \mathrm{C}-\mathrm{OH}$ & Carbohydrate, Monosaccharides \\
941,979 & $\mathrm{O}-\mathrm{C}=\mathrm{O}$ & alkane, glycosidic linkage \\
$600-650$ & & Acetate Ester \\
\hline
\end{tabular}

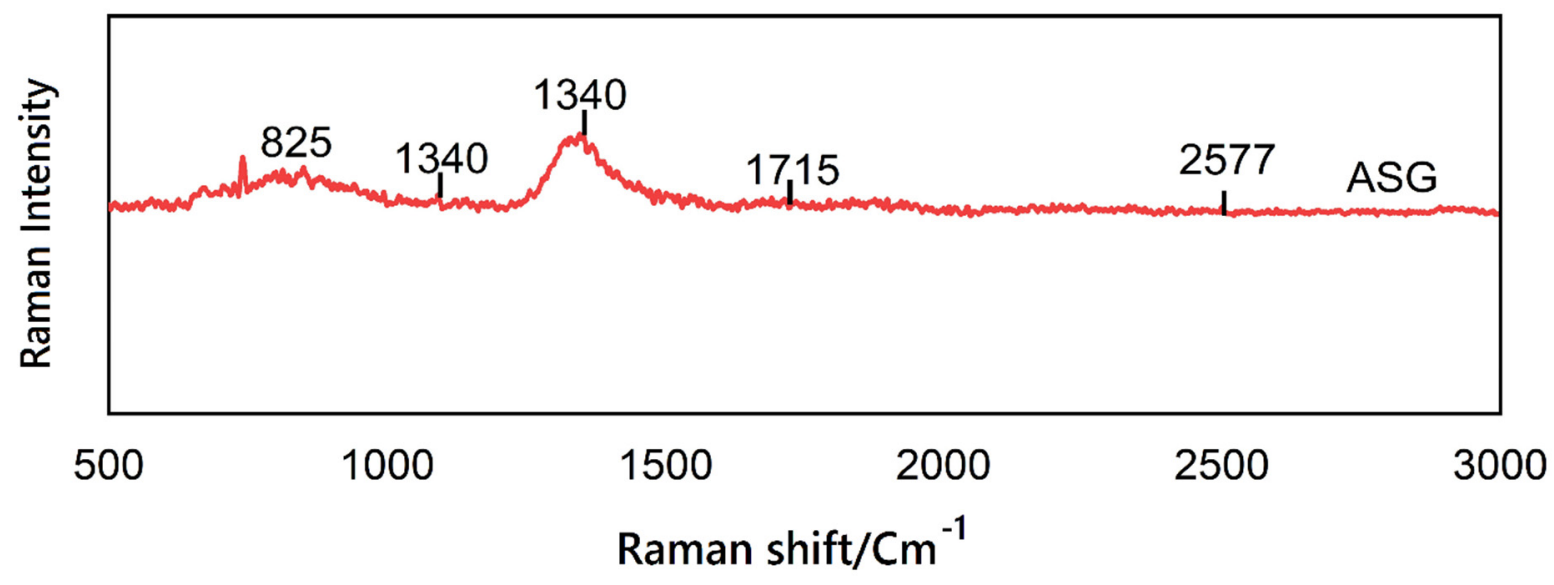

Figure 2. Typical Raman spectrum of Acacia Seyal gum powder sample.

In addition, Raman spectroscopy has been used to identify carotenoids and indolic alkaloids. Thus, the antioxidant activity of the crude extracts could therefore have revealed a potential function for bioactive substances. Thus, Raman bands at $1301 \mathrm{~cm}^{-1}$ assigned to $\mathrm{CH}_{2}$, which is assigned to carotenoids, and the bands at 1517 and $1000 \mathrm{~cm}^{-1}$ are typical bands for $\beta$-carotene [42]. At the region between 1600 and $1800 \mathrm{~cm}^{-1}$, Raman bands would expect the $\mathrm{C}=\mathrm{O}$ Alkyl ketone functional group, and a small contribution by the vibration of 
the $\mathrm{C}=\mathrm{C}$ groups is expected [43]. The approximate assignments of $\mathrm{OH}$ and $\mathrm{C}-\mathrm{C}$ aliphatic chain vibrations were found at $1155 \mathrm{~cm}^{-1}$ and $1266 \mathrm{~cm}^{-1}$, respectively [44]. A peak for NO2 symmetric stretching was detected at $1290 \mathrm{~cm}^{-1}$, whereas a peak for C-O stretching was seen at $1326 \mathrm{~cm}^{-1}$, while the region between 1400 and $1500 \mathrm{~cm}^{-1}$ displays $\mathrm{CH}_{2}$ and $\mathrm{CH}_{3}$ twists. Raman spectroscopy of phenolic antioxidants compound identification provides a systematic assessment of p-coumaric acid, sinapic acid, and caffeic acid (Table 4). Hence, Raman is considered as an effective tool for bioactive compounds discovery [45].

Polysaccharide vibrational bands characterized the Raman spectra of ASG. Weak and poorly resolved signals in wavenumbers above $1600 \mathrm{~cm}^{-1}$ explain the low-protein fractions. The results indicate that Raman spectroscopy may be a powerful technique to analyze the natural organic binding medium and identify function groups to effectively evaluate the antioxidant activity and health advantages of specific bioactive compounds in the pharmaceutical sectors.

\subsection{FTIR Analysis}

FTIR spectra were acquired for ASG extracts between 4000 and $400 \mathrm{~cm}^{-1}$. The resulting spectra revealed some substantial overlap of every absorption spectrum of the various components, in which each band presents the characteristic absorption peaks for functional groups obtained from the samples (Table 6). Based on Figure 3, the resulting FTIR spectra and the ASG ethanol crude extract spectra can have an excellent description. The FTIR spectrum of ASG samples had important peaks at approximately the same range of 3642, 2960, 2926, 2888, 2386, 2311, 2087, 2165, 1605, 1503, 1229, 1301, 1191, 1065, and $824 \mathrm{~cm}^{-1}$ (Figure 3). In the wavenumber's region, ASG showed three leading spectral bands connecting 1700 to $1200 \mathrm{~cm}^{-1}$. The band allocation may be partially related to the contribution of proteins in ASG. The different band at around $1602 \mathrm{~cm}^{-1}$ also presented characteristic bands of $\mathrm{C}, \mathrm{C}$ stretch, amide $\mathrm{NH}$ bend, and NO2 from both aliphatic and aromatic galactoproteins and amino acids. Amide I and amide II vibration bands are assumed to be nearly 1690 and $1480 \mathrm{~cm}^{-1}$ based on the literature for proteins in the FTIR spectra [46]. The groups are supposed to be primarily dependent on the polypeptide backbone secondary structure and not often affected by the characteristics of the side chains $[47,48]$. Therefore, gum Arabic has distinctive polyphenolics bands with different vibration occurrences. A clear stretch of $\mathrm{C}-\mathrm{C}$ stretch, amide $\mathrm{NH}$ bend, and $\mathrm{NO}_{2}$ from both aliphatic and aromatic galactoproteins and amino acids can be seen at approximately $1615 \mathrm{~cm}^{-1}$ [49]. Saturated Aliphatic (alkene/alkyl) $\mathrm{CH}_{3}$ bend was stated in a wavenumber region at $2960-2880 \mathrm{~cm}^{-1}$ [50]. At a medium band in the region of $1250-1020 \mathrm{~cm}^{-1}$, amine C-N stretch was observed [51].

At the area of 3285-2600 $\mathrm{cm}^{-1}$, the FTIR spectrum showed a broad OH stretching vibration in carboxylic acids, while the same area of the stretching vibration region for carbon and aromatic C-H groups also showed FTIR spectra of specific polysaccharides [52]. However, the band position near $1229 \mathrm{~cm}^{-1}$ was found to depend on the biochemical composition and specifically the phenol content [53]. Therefore, additional studies are needed for identifying the specific functional groups in gum Arabic. The raw ASG contains glucuronic acid content in a considerable amount and a low content of proteins. As a result, the assignment of the absorbance bands at $1608 \mathrm{~cm}^{-1}$ suggests a carbonyl C-O that could be because of glucuronic acid in the ASG spectrum [54]. Moreover, IR bands at $1301 \mathrm{~cm}^{-1}$ with the bending of secondary aromatic amines showed the contribution of proteins' imines [55]. This segment, also known as the carbohydrate fingerprint region, is created by the side chains of polysaccharides and skeletal stretching vibrations. Even though the band at $2159 \mathrm{~cm}^{-1}$ represents the ethene $\mathrm{CH}$ antisymmetric stretch compound and $\mathrm{CH}_{2}=\mathrm{CH}_{2}$ as a functional group, the bands at $2926 \mathrm{~cm}^{-1}$ indicate the presence of the most frequent plant gum polysaccharides like sugars, galactose, arabinose, and rhamnose as well as the presence of alkane, and these results agreed with Daoub et al. [55], who performed an FTIR study of Acacia gum. The maximum ASG absorbance peaks found at $1747 \mathrm{~cm}^{-1}$ somewhere in the infrared spectral bands between 1200 and $824 \mathrm{~cm}^{-1}$ are 
difficult for interpretation and were thought to relate to the carbohydrate group of Acacia gums. The skeletal stretching vibrations and the polysaccharides' side chains create this socalled carbohydrate fingerprint area, which is controlled by ring vibration with extending vibrations. They are consistent with the FTIR study on raw Acacia Senegal and ASG carried out by Lopez-Torrez et al. [56]. The results showed the existence of alcohol, alkanes, aromatics, imines or ketones, alkenes, phenols, and amines functional groups.

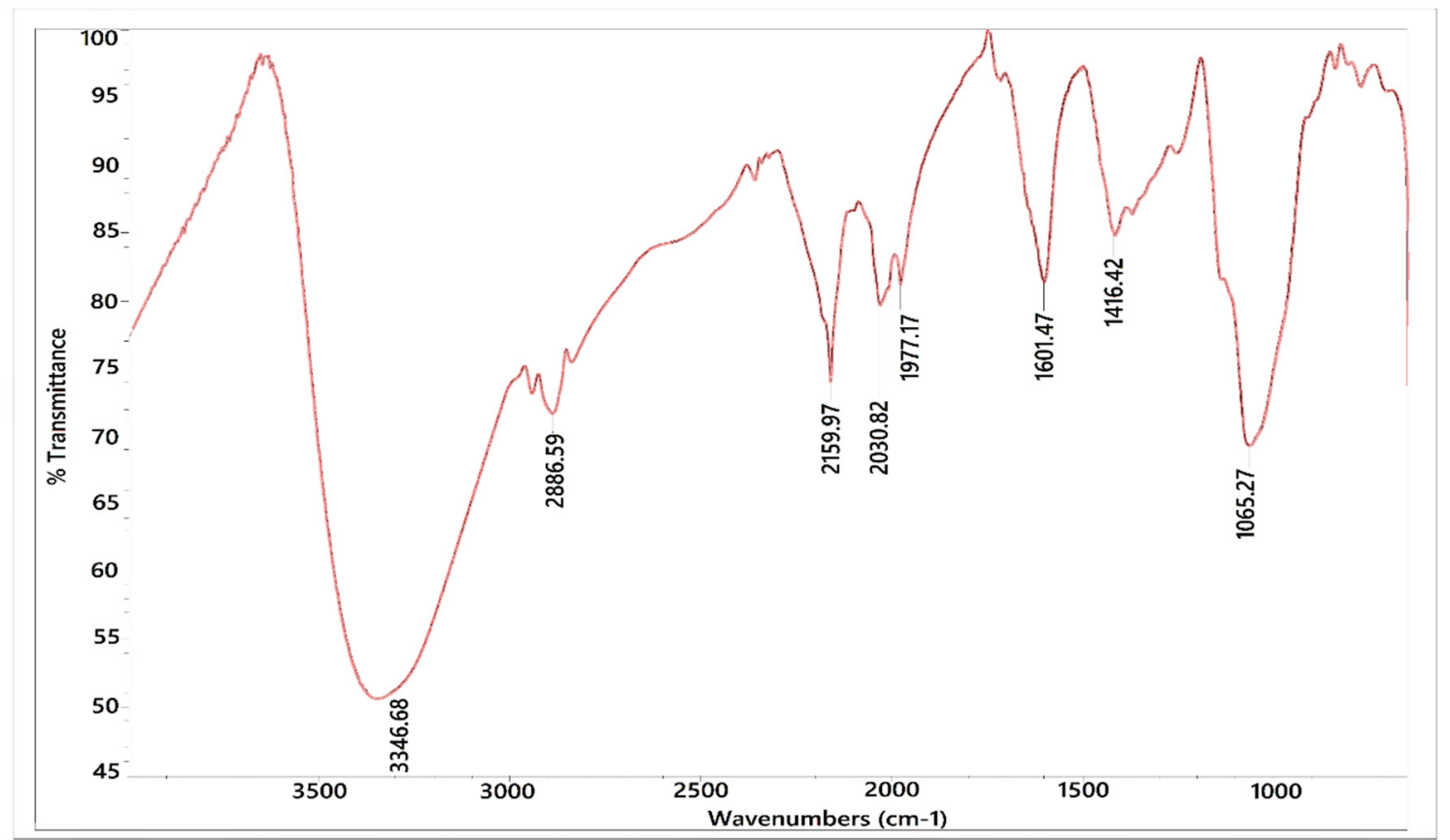

Figure 3. FTIR spectra in the region of $400-4000 \mathrm{~cm}^{-1}$ Acacia Seyal gum powder sample.

Table 6. Main functional groups assigned to the different vibrations present in FTIR spectra.

\begin{tabular}{ccc}
\hline Possible Band Assignment & Wavenumber $\left.\mathbf{( c m}^{-\mathbf{1}}\right)$ & Functional Group \\
\hline $\mathrm{O}-\mathrm{H} \cdots \mathrm{O}$ & 3347 & Alcohol and hydroxy compound [50] \\
$\mathrm{C}-\mathrm{H}$ or $/$ and $\mathrm{NH}_{3}$ & 2888 & amino acids [52] \\
OH stretch & 3642 & Primary alcohol \\
$\mathrm{C}-\mathrm{H}$ & 2960 & alkene/alkyl \\
$\mathrm{CH}_{2}=\mathrm{CH}_{2}$ & 2927 & Alkene \\
$\mathrm{C}-\mathrm{H}$ stretching & 2087 & Aldehyde \\
$\mathrm{C}=\mathrm{O}$ & $1731-1713$ & ketones \\
& $1730-1705$ & Ketone [54] \\
$\mathrm{C}=\mathrm{C}$ & 1624 & Alkene [53] \\
Phenolic $\mathrm{OH}$ & 1229 & \\
$\mathrm{C}-\mathrm{N}$ & 1301 & Secondary amides [53] \\
$\mathrm{C}-\mathrm{O}-\mathrm{C}$ & 1140 & Ether [56] \\
$\mathrm{CN}$ stretch & 1065 & Primary amine \\
C-H aromatic & 824 & alkene \\
\hline
\end{tabular}

Based on the above interpretation, the spectroscopic description of the ASG and its elements (phenolics and polysaccharides) by FTIR showed the presence of aromatic galactoproteins, and amino acids with sugars, galactose, arabinose, and rhamnose. These distinct peaks may offer a simple, quick, and low-cost method of identification. However, these findings provide a solid foundation for follow-up research on ASG. 


\subsection{Chemical Profile of Ethanol ASG Extract Using GC-TOFMS}

The GC-TOFMS analysis used for the identification of chemical constituents of the ethanol extract of ASG was performed using a time-of-flight mass spectrometry GC-TOFMS apparatus, which is frequently employed in the field of cultural heritage to identify the sugar content of polysaccharide materials [57]. These chemicals identified by GC-TOFMS analysis were compared to compounds found in earlier Arabic gum studies. More detailed analysis was done; however, some of their activities were identified and reported and others were not. The chemical profile of ASG was determined by comparing the similarity of the pattern resulting from the GC-TOFMS reading with the pattern of the available database, which revealed the presence of several chemical constituents that have been reported to have many therapeutic values and biological properties. This list of compounds identified by GC-TOFMS analysis was compared with compounds in the library of ASG extract phytochemical analysis. More detailed analysis was done for those compounds, and their activities were identified and reported. The constituents of ASG generally belong to the class of polysaccharide, alkaloids, flavonoids, phenols, and tannins. According to many previous studies, these groups of compounds have potential activity as antidiabetic, antioxidant, and anticancer compounds. The result of the GC-TOFMS analysis of the ethanolic extract ASG is shown in Table 7 where the interpretation of mass spectrum of GCMS was done using the database of the National Institute Standard and Technology (NIST), and the mass spectrum of the unknown component was compared with the spectrum of the known component stored in the NIST library. The compound name, probability, molecular formula, molecular weight, and biological activity of the test materials were determined.

Table 7. List of compounds of ASG ethanolic extracts observed in GC-TOFMS with their retention time and biological activity.

\begin{tabular}{|c|c|c|c|c|c|}
\hline Compound Name & $\begin{array}{c}\mathrm{RT} \\
(\mathrm{min})\end{array}$ & M.F & $\begin{array}{c}\text { M.W } \\
(\mathrm{g} / \mathrm{mol})\end{array}$ & Biological Activity & Reference. \\
\hline Lupulon & 14.28 & $\mathrm{C}_{26} \mathrm{H}_{38} \mathrm{O}_{4}$ & 414 & antimicrobial & [58] \\
\hline $\begin{array}{l}\text { 2-Butynedioic acid } \\
\text { Acetylenedicarboxylic acid }\end{array}$ & 59.719 & $\mathrm{C}_{4} \mathrm{H}_{2} \mathrm{O}_{4}$ & 114 & antibacterial potency & {$[59]$} \\
\hline 7-Methyl-Z-tetradecen-1-ol acetate & 29.71 & $\mathrm{C}_{17} \mathrm{H}_{32} \mathrm{O}_{2}$ & 268 & anti-inflammatory & {$[60]$} \\
\hline 9-Octadecenal & 19.52 .78 & $\mathrm{C}_{18} \mathrm{H}_{34}$ & 266 & $\begin{array}{c}\text { antibacterial } \\
\text { Membrane stabilizer }\end{array}$ & {$[61]$} \\
\hline Benzene, 1,3,5-trimethyl-2-octadecyl & 51 & $\mathrm{C}_{27} \mathrm{H}_{48}$ & 372 & not reported & \\
\hline Cyclobarbital & 55.4 & $\mathrm{C}_{12} \mathrm{H}_{16} \mathrm{~N}_{2} \mathrm{O}_{3}$ & 23 & anti-proliferative & {$[62]$} \\
\hline Rhodoviolascin & 57 & $\mathrm{C}_{42} \mathrm{H}_{60} \mathrm{O}_{2}$ & 597 & $\begin{array}{l}\text { bacterial metabolite. } \\
\text { antioxidant }\end{array}$ & [63] \\
\hline$\beta$-Carotene & 56 & $\mathrm{C}_{40} \mathrm{H}_{56}$ & 537 & antioxidant & [64] \\
\hline 2,4-Dimethoxycinnamic acid & 2 & $\mathrm{C}_{11} \mathrm{H}_{12} \mathrm{O}_{4}$ & 208 & cytotoxic activity & [65] \\
\hline Benzoic acid 2-methylpentyl ester & 61 & $\mathrm{C}_{13} \mathrm{H}_{18} \mathrm{O}_{2}$ & 206 & antimicrobial & [66] \\
\hline 2-Phenylindolizine & 64 & $\mathrm{C}_{14} \mathrm{H}_{11} \mathrm{~N}$ & 193 & $\begin{array}{l}\text { antimicrobial activity } \\
\text { antimicrobial }\end{array}$ & [67] \\
\hline Cyclotrisiloxane, hexamethyl & 64 & $\mathrm{C}_{6} \mathrm{H}_{18} \mathrm{O}_{3} \mathrm{Si}_{3}$ & 222 & $\begin{array}{l}\text { antibacterial and antioxidant } \\
\text { activity }\end{array}$ & [68-70] \\
\hline Chlortetracycline & 58 & $\mathrm{C}_{22} \mathrm{H}_{24} \mathrm{Cl}_{2} \mathrm{~N}_{2} \mathrm{O}_{8}$ & 515 & antibacterial agents & {$[71]$} \\
\hline Astaxanthin & 58 & $\mathrm{C}_{40} \mathrm{H}_{52} \mathrm{O}_{4}$ & 596 & $\begin{array}{l}\text { antioxidant } \\
\text { anticancer }\end{array}$ & [72] \\
\hline Acridine, 9-methyl- & 64 & $\mathrm{C}_{14} \mathrm{H}_{11} \mathrm{~N}$ & 193 & not reported & \\
\hline Isopilocarpine & 63 & $\mathrm{C}_{11} \mathrm{H}_{16} \mathrm{~N}_{2} \mathrm{O}_{2}$ & 208 & antimicrobial & [73] \\
\hline Betamethasone & 56 & $\mathrm{C}_{22} \mathrm{H}_{29} \mathrm{FO}_{5}$ & 392 & anti-inflammatory & [74] \\
\hline Benzo[h]quinoline,2,4 dimethyl- & 56 & $\mathrm{C}_{15} \mathrm{H}_{13} \mathrm{~N}$ & 207 & anticancer & [75] \\
\hline $\begin{array}{c}\text { Benzamide, } \\
\text { N-ethyl-N-(3-methylphenyl)-4-ethyl- }\end{array}$ & 57 & $\mathrm{C}_{17} \mathrm{H}_{19} \mathrm{NO}$ & 253 & antibacterial & [76] \\
\hline Pyrrolidine, 1-(1-oxo-5,8-octadecadienyl) & 59.62 & $\mathrm{C}_{18} \mathrm{H}_{31} \mathrm{NO}$ & 277 & $\begin{array}{l}\text { anti-inflammatory and antitumor } \\
\text { activity }\end{array}$ & [77] \\
\hline $\begin{array}{c}\text { 5H-Cyclohepta[b]pyridine-3- } \\
\text { carbonitrile,6,7,8,9-tetrahydro-2-amino-4-(2- } \\
\text { fluorophenyl)- }\end{array}$ & 61.85 & $\mathrm{C}_{11} \mathrm{H}_{12} \mathrm{~N}_{2}$ & 172 & not reported & \\
\hline Lycopene & 63.84 & $\mathrm{C}_{40} \mathrm{H}_{56}$ & 69 & antioxidant & [78] \\
\hline $\begin{array}{l}\text { Trisiloxane, 1,1,1,5,5,5-hexamethyl-3,3- } \\
\text { bis[(trimethylsilyl)oxy]- }\end{array}$ & 56.47 & $\mathrm{C}_{12} \mathrm{H}_{36} \mathrm{O}_{4} \mathrm{Si}_{5}$ & 384 & antioxidant & [79] \\
\hline 1,3-Dioxolane,2-(1 phenylethyl) & 62.24 & $\mathrm{C}_{11} \mathrm{H}_{14} \mathrm{O}_{2}$ & 178 & not reported & \\
\hline
\end{tabular}


Table 7. Cont.

\begin{tabular}{|c|c|c|c|c|c|}
\hline Compound Name & $\begin{array}{c}\mathrm{RT} \\
(\mathrm{min})\end{array}$ & M.F & $\begin{array}{c}\text { M.W } \\
(\mathrm{g} / \mathrm{mol})\end{array}$ & Biological Activity & Reference. \\
\hline $\begin{array}{c}\text { D-Glucopyranosiduronic acid, } \\
\text { 3-(5-ethylhexahydro-1,3-dimethyl-2,4,6- } \\
\text { trioxo-5-pyrimidinyl)-1-methylbutyl } \\
\text { 2,3,4-tris-O-(trimethylsilyl) }\end{array}$ & 59.1 & $\mathrm{C}_{29} \mathrm{H}_{56} \mathrm{~N}_{2} \mathrm{O}_{10} \mathrm{Si}_{3}$ & 677 & antibacterial and antioxidant & [80] \\
\hline Oxazolam & 60.85 & $\mathrm{C}_{18} \mathrm{H}_{17} \mathrm{ClN}_{2} \mathrm{O}_{2}$ & 328 & muscle relaxants & [81] \\
\hline $\begin{array}{c}\text { Cyclohexyldimethylsilyloxy-3- } \\
\text { phenylpropane }\end{array}$ & 50 & $\mathrm{C}_{15} \mathrm{H}_{22} \mathrm{O}_{2}$ & 330 & $\begin{array}{c}\text { anticancer and antitumor } \\
\text { activities }\end{array}$ & [82-84] \\
\hline $\begin{array}{c}\text { Glycine,N-[(3à,5á,7à,12à)-24-oxo-3,7,12 } \\
\text { tris[(trimethylsilyl)oxy]cholan-24-yl]- } \\
\text {,methyl } \\
\text { ester }\end{array}$ & 10 & $\mathrm{C}_{32} \mathrm{H}_{38} \mathrm{~N}_{2} \mathrm{O}_{8}$ & 578 & antihypertensive action & [85] \\
\hline 1,2-Benzisothiazol-3-amine tbdms & 4 & $\mathrm{C}_{13} \mathrm{H}_{20} \mathrm{~N}_{2} \mathrm{SSi}$ & 264 & antifungal activity & {$[86]$} \\
\hline R)-(-)-2-Amino-1-propanol & 12 & $\mathrm{C}_{3} \mathrm{H}_{9} \mathrm{NO}$ & 75 & $\begin{array}{l}\text { antioxidant and antiproliferative } \\
\text { activity }\end{array}$ & [87] \\
\hline Silicic acid, diethyl bis(trimethylsilyl) ester & 57 & $\mathrm{C}_{10} \mathrm{H}_{28} \mathrm{O}_{4} \mathrm{Si}$ & 296 & $\begin{array}{c}\text { antibacterial } \\
\text { antioxidant activity }\end{array}$ & {$[88,89]$} \\
\hline $\begin{array}{l}\text { 6,9,10-Trimethoxy-12H-benz }(6,7) \\
\text { oxepino }(2,3,4 \text {-i,j)isoquinoline }\end{array}$ & 23 & $\mathrm{C}_{19} \mathrm{H}_{17} \mathrm{NO}_{4}$ & 323 & antitumor & [90] \\
\hline $\begin{array}{l}\text { N, N-dimethyl-4-nitroso-3-(trimethylsilyl) } \\
\text { aniline }\end{array}$ & 30 & $\mathrm{C}_{11} \mathrm{H}_{18} \mathrm{NOSi}_{2}$ & 222 & antitumor activity & [91] \\
\hline
\end{tabular}

A GC-TOFMS analysis in this study of an ethanolic extract of ASG revealed the presence of different phytochemicals that may contribute to the plant's therapeutic bioactivity. The GC-TOFMS spectrum approved the presence of different components with different retention times as illustrated in Table 7 . However, the observed mass spectra consider the fingerprint of these compound that can be identified from the data library. It was widely reported that Arabic gum contained a considerable number of phytochemicals that exhibit antioxidant activity and can combat many diseases such as renal, cardiovascular, gastrointestinal, and respiratory diseases, due to its agonist effect on the oxidative stress and DNA damage [92]. Furthermore, Badreldin et al. verified the antioxidative and anti-inflammatory properties of $A G$. It was found that amino-saccharins like 1,2-Benzisothiazol-3-amine which is one of tert-butyldimethylsilyl (TBDMS) derivatives which are considered to be antioxidant compounds, were investigated previously in the methanol extract of Dillenia scabrella. The 1,2,3,12a-Tetrahydro-6,9,10-trimethoxy-2-oxo-12H-benz(6,7) oxepino(2,3,4-i,j) isoquinoline alkaloid compound with antitumor activity was also detected and reported on by various researchers for its biological activities [93]. R)-(-)-2-Amino-1-propanol (alaninol) is one of the amino alcohol derivatives that poses antioxidant and anti-proliferative activity [94]. Compound like Monoalkylamines, isobutylamine, and N, N-dimethyl-4-nitroso3-(trimethylsilyl) aniline, are phenylamine compounds with antitumor activity found in the analysis results [95]. 9,12,15-Octadecatrienoic acid, 2,3-bis [(trimethylsilyl) oxy] propyl ester, $(Z, Z, Z)$ are also anti-inflammatory, hypocholesterolemia, and cancer-preventive compounds $[96,97]$. Astaxanthin, $\beta$-carotene, Phenylindolizine, and similar types of compounds were identified in methanol extract of ASG [98]. Although the previous literature survey confirmed the occurrence of 2,4-Dimethoxycinnamic acid [98] and cyclobarbital from various plant sources $[99,100]$, there is no report of GC-TOFMS-based metabolite profiling to detect the unique presence of benzodioxole and barbital derivatives from any part of ASG. Cyclobarbital, also shown in the results, which is used therapeutically in the treatment of insomnia and as an anesthetic, anti-convulsant, and skeletal or muscle relaxant in recent times, has also been also reported to have anti-proliferative potential [62] Other compounds were also present, like Cyclotrisiloxane and hexamethyl- which had broad-spectrum antimicrobial activity, so we concluded that ethanol extracts of ASG can be a good source of antioxidant and antimicrobial compounds $[69,70]$ discovered that Spirilloxanthin, Rhodoviolascin, $\beta$-carotene, lycopene, and astaxanthin are carotenoids that play an important role as antioxidants; besides that, they have potential therapeutic significance in pain and inflammation management [101,102]. Another compound was 
reported Deserpidine, which is a naturally occurring alkaloid that has been used for the treatment of hypertension and as a tranquilizer. In addition, it appears to act as a controller of other cardiac disorders [84]. These identified compounds were observed to be present in the extract of different plant parts and exhibiting different biological activity, for example anticancer activity.

\section{Conclusions}

The green extraction technique (UAE) can be a potential alternative for conventional extraction methods since it improves the yield and quality of the extract. The RSM generated optimum extraction conditions as follows: $40{ }^{\circ} \mathrm{C}$ of extraction temperature, $45 \mathrm{~min}$ of extraction time, and $1: 25 \mathrm{~g} / \mathrm{mL}$ of solid-liquid ratio. This could be utilized in future ASG extractions on a larger scale by considering these parameters for economic evaluation. Moreover, the outcomes from the RAMAN, FTIR, and GC-TOFMS profile suggest that ASG gum phytochemical compounds could be a potent source for active natural compounds like glycosides, alkaloid, triterpenes, flavonoids, quinones, coumarins, and polyphenolic compounds that could be used to develop novel therapeutic agents for a variety of diseases. They might also be a possible reason to exhibit anticancer, antioxidant, and antibacterial activities. This study could be useful to lead the path for future developments of pharmaceutical applications of ASG.

Author Contributions: Conceptualization, T.M.; data curation, T.M.; formal analysis, T.M.; investigation, N.A.K.; methodology, T.M. and D.D.; supervision, N.A.K.; validation, T.M. and N.A.K.; visualization, T.M.; writing—original draft, T.M. and F.A; writing—review and editing, T.M., N.A.K., D.D., F.A., M.E.S.M., M.Z.A., M.F.H.R., A.M., J.I.O. and M.K.A.A.R. All authors have read and agreed to the published version of the manuscript.

Funding: The APC was funded by Universiti Malaysia Kelantan and Universiti Sains Malaysia.

Institutional Review Board Statement: Not applicable.

Informed Consent Statement: Not applicable.

Data Availability Statement: The data presented in this study are available within the article.

Acknowledgments: The authors are grateful to the International Islamic University of Malaysia, Biotechnology Engineering department for providing laboratory facilities.

Conflicts of Interest: The authors declare no conflict of interest.

\section{References}

1. Adwan, G.; Abu-Shanab, B.; Adwan, K. Antibacterial activities of some plant extracts alone and in combination with different antimicrobials against multidrug-resistant Pseudomonas aeruginosa strains. Asian Pac. J. Trop. Med. 2010, 3, 266-269. [CrossRef]

2. Chinembiri, T.N.; Du Plessis, L.H.; Gerber, M.; Hamman, J.H.; Du Plessis, J. Review of Natural Compounds for Potential Skin Cancer Treatment. Molecules 2014, 19, 11679-11721. [CrossRef]

3. Elmi, A.; Spina, R.; Risler, A.; Philippot, S.; Mérito, A.; Duval, R.E.; Laurain-Mattar, D. Evaluation of antioxidant and antibacterial activities, cytotoxicity of acacia seyal del bark extracts and isolated compounds. Molecules 2020, 25, 2392. [CrossRef]

4. Hammiche, V.; Maiza, K. Traditional medicine in Central Sahara: Pharmacopoeia of Tassili N'ajjer. J. Ethnopharmacol. 2006, 105, 358-367. [CrossRef] [PubMed]

5. Sadiq, M.B.; Hanpithakpong, W.; Trning, J.; Anal, A.K. Screening of phytochemicals and in vitro evaluation of antibacterial and antioxidant activities of leaves, pods and bark extracts of Acacia nilotica (L.) Del. Ind. Crops Prod. 2015, 77, 873-882. [CrossRef]

6. Singh, B.N.; Singh, B.R.; Singh, R.L.; Prakash, D.; Sarma, B.K.; Singh, H.B. Antioxidant and anti-quorum sensing activities of green pod of Acacia nilotica L. Food Chem. Toxicol. 2009, 47, 778-786. [CrossRef] [PubMed]

7. Cowan, M.M. Plant products as antimicrobial agents. Clin. Microbiol. Rev. 1999, 12, 564-582. [CrossRef]

8. Capitata, L. Quantification of flavonoids by UPLC-MS and its antibacterial activity from Brassica. GSC Biol. Pharm. Sci. 2018, 5, 109-114.

9. Revathi, S.; Govindarajan, R.K.; Rameshkumar, N.; Hakkim, F.L.; Mohammed, A.B.; Krishnan, M.; Kayalvizhi, N. Anti-cancer, anti-microbial and anti-oxidant properties of Acacia nilotica and their chemical profiling. Biocatal. Agric. Biotechnol. 2017, 11, 322-329. [CrossRef]

10. Zhang, Q.W.; Lin, L.G.; Ye, W.C. Techniques for extraction and isolation of natural products: A comprehensive review. Chin. Med. 2018, 13, 1-26. [CrossRef] 
11. Chemat, F.; Rombaut, N.; Sicaire, A.G.; Meullemiestre, A.; Fabiano-Tixier, A.S.; Abert-Vian, M. Ultrasound assisted extraction of food and natural products. Mechanisms, techniques, combinations, protocols and applications. A review. Ultrason. Sonochem. 2017, 34, 540-560. [CrossRef] [PubMed]

12. Zahari, N.A.A.R.; Chong, G.H.; Abdullah, L.C.; Chua, B.L. Ultrasonic-assisted extraction (UAE) process on thymol concentration from Plectranthus amboinicus leaves: Kinetic modeling and optimization. Processes 2020, 8, 322. [CrossRef]

13. Che Sulaiman, I.S.; Basri, M.; Fard Masoumi, H.R.; Chee, W.J.; Ashari, S.E.; Ismail, M. Effects of temperature, time, and solvent ratio on the extraction of phenolic compounds and the anti-radical activity of Clinacanthus nutans Lindau leaves by response surface methodology. Chem. Cent. J. 2017, 11,1-11. [CrossRef] [PubMed]

14. Fan, S.; Yang, G.; Zhang, J.; Li, J.; Bai, B. Optimization of ultrasound-assisted extraction using response surface methodology for simultaneous quantitation of six flavonoids in flos Sophorae immaturus and antioxidant activity. Molecules 2020, $25,1767$. [CrossRef] [PubMed]

15. Abdulhafiz, F.; Mohammed, A.; Kayat, F.; Zakaria, S.; Hamzah, Z.; Reddy Pamuru, R.; Reduan, M.F.H. Micropropagation of Alocasia longiloba Miq and comparative antioxidant properties of ethanolic extracts of the field-grown plant, in vitro propagated and in vitro-derived callus. Plants 2020, 9, 816. [CrossRef]

16. Maher, T.; Ahmad Raus, R.; Daddiouaissa, D.; Ahmad, F.; Adzhar, N.S.; Latif, E.S.; Mohammed, A. Medicinal Plants with Anti-Leukemic Effects: A Review. Molecules 2021, 26, 2741. [CrossRef]

17. Abdulhafiz, F.; Mohammed, A.; Kayat, F.; Bhaskar, M.; Hamzah, Z.; Podapati, S.K.; Reddy, L.V. Xanthine oxidase inhibitory activity, chemical composition, antioxidant properties and GC-MS Analysis of Keladi Candik (Alocasia longiloba Miq). Molecules 2020, 25, 2658. [CrossRef]

18. Huang, C.C. Applications of Raman spectroscopy in herbal medicine. Appl. Spectrosc. Rev. 2016, 51, 1-11. [CrossRef]

19. Vankeirsbilck, T.; Vercauteren, A.; Baeyens, W.; Van der Weken, G.; Verpoort, F.; Vergote, G.; Remon, J.P. Applications of Raman spectroscopy in pharmaceutical analysis. Trends Anal. Chem. 2002, 21, 869-877. [CrossRef]

20. Berthomieu, C.; Hienerwadel, R. Fourier transform infrared (FTIR) spectroscopy. Photosynth. Res. 2009, 101, 157-170. [CrossRef]

21. Farnev, K.F.; Tijjani, M.A.; Shamaki, U.B. Isolation and identification of compounds in the leaf Ficus sycomorus Linn Moraceae by Gas Chromatography-Mass Spectrometry, Infra-red and Ultraviolet Spectroscopy. J. Chem. Lett. 2021, 2, 33-42.

22. Esmaeili, F.; Hashemiravan, M.; Eshaghi, M.R.; Gandomi, H. Optimization of Aqueous Extraction Conditions of Inulin from the Arctium lappa L. Roots Using Ultrasonic Irradiation Frequency. J. Food Qual. 2021, 2021, 5520996. [CrossRef]

23. Elnour, A.A.M.; Mirghani, M.E.S.; Kabbashi, N.A.; Alam, M.Z. Musa, K.H. Gum arabic: An optimization of ultrasonic-assisted extraction of antioxidant activity. Stud. Univ. Babes-Bolyai Chem. 2018, 63, 95-116.

24. Elnour, A.A.; Mirghani, M.E.S.; Kabbashi, N.A.; Alam, M.Z.; Musa, K.H. Active Fractions of Methanol Crude Obtained from Acacia seyal gum: Antioxidant Capacity using FTIR Analysis. Borneo J. Pharm. 2019, 2, 94-107. [CrossRef]

25. Koocheki, A.; Mortazavi, S.A.; Shahidi, F.; Razavi, S.M.A.; Kadkhodaee, R.; Milani, J.M. Optimization of mucilage extraction from Qodume Shirazi seed (Alyssum homolocarpum) using response surface methodology. J. Food Process Eng. 2010, 33, 861-882. [CrossRef]

26. Daddiouaissa, D.; Amid, A.; Sani, M.S.A.; Elnour, A.A. Evaluation of metabolomics behavior of human colon cancer HT29 cell lines treated with ionic liquid graviola fruit pulp extract. J. Ethnopharmacol. 2021, 270, 113813. [CrossRef]

27. Ma, C.H.; Liu, T.T.; Yang, L.; Zu, Y.G.; Chen, X.; Zhang, L.; Zhao, C. Ionic liquid-based microwave-assisted extraction of essential oil and biphenyl cyclooctene lignans from Schisandra chinensis Baill fruits. J. Chromatogr. A 2011, 1218, 8573-8580. [CrossRef]

28. Chan, C.H.; See, T.Y.; Yusoff, R.; Ngoh, G.C.; Kow, K.W. Extraction of bioactives from Orthosiphon stamineus using microwave and ultrasound-assisted techniques: Process optimization and scale up. Food Chem. 2017, 221, 1382-1387. [CrossRef]

29. Elnour, A.A.M.; Mirghani, M.E.S.; Kabbashi, N.A.; Alam, M.Z. Significant bioactive compounds in crude methanol extracts and their fractions of acacia seyal gum. Int. J. Sudan Res. 2019, 8, 99-112. [CrossRef]

30. Bi, J.; Yang, Q.; Sun, J.; Chen, J.; Zhang, J. Study on ultrasonic extraction technology and oxidation resistance of total flavonoids from peanut hull. J. Food Sci. Technol. 2011, 17, 187-198. [CrossRef]

31. Liu, Z.W.; Zeng, X.A.; Ngadi, M. Enhanced extraction of phenolic compounds from onion by pulsed electric field (PEF). J. Food Process. Preserv. 2018, 42, 4-11. [CrossRef]

32. Freire, P.T.C.; Barboza, F.M.; Lima, J.A.; Melo, F.E.A.; Filho, J.M. Raman Spectroscopy of Amino Acid Crystals. In Raman Spectroscopy and Applications; Intech: Rijeka, Croatia, 2017; Volume 201.

33. Gosselin, M.È.; Kapustij, C.J.; Venkateswaran, U.D.; Leverenz, V.R.; Giblin, F.J. Raman spectroscopic evidence for nuclear disulfide in isolated lenses of hyperbaric oxygen-treated guinea pigs. Exp. Eye Res. 2007, 84, 493-499. [CrossRef]

34. De Pinto, G.L.; Martínez, M.; Ortega, S.; Villavicencio, N.; Borjas, L. Comparison of gum specimens from Acacia tortuosa and other Gummiferae species. Biochem. Syst. Ecol. 1993, 21, 795-797. [CrossRef]

35. Wiercigroch, E.; Szafraniec, E.; Czamara, K.; Pacia, M.Z.; Majzner, K.; Kochan, K.; Kaczor, A.; Baranska, M.; Malek, K. Raman and infrared spectroscopy of carbohydrates: A review. Spectrochim. Acta-A Mol. Biomol. Spectrosc. 2017, 185, 317-335. [CrossRef] [PubMed]

36. Capek, P.; Drábik, M.; Turjan, J. Characterization of starch and its mono and hybrid derivatives by thermal analysis and FT-IR spectroscopy. J. Therm. Anal. Calorim. 2010, 99, 667-673. [CrossRef]

37. Vandenabeele, P.; Wehling, B.; Moens, L.; Edwards, H.; De Reu, M.; Van Hooydonk, G. Analysis with micro-Raman spectroscopy of natural organic binding media and varnishes used in art. Anal. Chim. Acta 2000, 407, 261-274. [CrossRef] 
38. De Veij, M.; Vandenabeele, P.; De Beer, T.; Remon, J.P.; Moens, L. Reference database of Raman spectra of pharmaceutical excipients. J. Raman Spectrosc. 2009, 40, 297-307. [CrossRef]

39. Czamara, K.; Majzner, K.; Pacia, M.Z.; Kochan, K.; Kaczor, A.; Baranska, M. Raman spectroscopy of lipids: A review. J. Raman Spectrosc. 2015, 46, 4-20. [CrossRef]

40. Calheiros, R.; Machado, N.F.L.; Fiuza, S.M.; Gaspar, A.; Garrido, J.; Milhazes, N.; Borges, F.; Marques, M.P.M. Antioxidant phenolic esters with potential anticancer activity: A Raman spectroscopy study. J. Raman Spectrosc. 2008, 39, 95-107. [CrossRef]

41. Machado, N.F.L.; Calheiros, R.; Gaspar, A.; Garrido, J.; Borges, F.; Marques, M.P.M. Antioxidant phenolic esters with potential anticancer activity: Solution equilibria studied by Raman spectroscopy. J. Raman Spectrosc. 2009, 40, 80-85. [CrossRef]

42. Maia, L.F.; Fernandes, R.F.; Lobo-Hajdu, G.; De Oliveira, L.F.C. Conjugated polyenes as chemical probes of life signature: Use of Raman spectroscopy to differentiate polyenic pigments. Philos. Trans. R. Soc. A Math. Phys. Eng. Sci. 2014, 372, 20140200. [CrossRef]

43. Edwards, H.G.M. Spectra-structure correlations in Raman spectroscopy. In Handbook of Vibrational Spectroscopy; John Wiley \& Sons: Chichester, UK, 2002; Volume 3, pp. 1838-1871.

44. Morales-Tovar, M.E.; Ramos-Ramírez, E.G.; Salazar-Montoya, J.A. Modeling and optimization of the parameters affecting extraction of the chan seed mucilage (Hyptis suaveolens (L.) Poit) by mechanical agitation (MA) and ultrasound-assisted extraction (UAE) in a multiple variables system. Food Bioprod. Process. 2020, 120, 166-178. [CrossRef]

45. Aguilar-Hernández, I.; Afseth, N.K.; López-Luke, T.; Contreras-Torres, F.F.; Wold, J.P.; Ornelas-Soto, N. Surface enhanced Raman spectroscopy of phenolic antioxidants: A systematic evaluation of ferulic acid, p-coumaric acid, caffeic acid and sinapic acid. Vib. Spectrosc. 2017, 89, 113-122. [CrossRef]

46. Kong, J.; Yu, S. Fourier transform infrared spectroscopic analysis of protein secondary structures. Acta Biochim. Biophys. Sin. 2007, 39, 549-559. [CrossRef] [PubMed]

47. Ramos, J.M.; Mauŕicio, M.T.; Costa, A.C.; Versiane, O.; Soto, C.A.T. Fourier transform infrared spectrum: Vibrational assignments using density functional theory and natural bond orbital analysis of the bis (guanidoacetate) nickel(II) complex. ScienceAsia 2011, 37, 247-255. [CrossRef]

48. Barth, A.; Zscherp, C. What vibrations tell about proteins. Q. Rev. Biophys. 2002, 35, 369-430. [CrossRef]

49. Abidi, N.; Cabrales, L.; Haigler, C.H. Changes in the cell wall and cellulose content of developing cotton fibers investigated by FTIR spectroscopy. Carbohydr. Polym. 2014, 100, 9-16. [CrossRef]

50. Nandiyanto, A.B.D.; Oktiani, R.; Ragadhita, R. How to read and interpret ftir spectroscope of organic material. Indones. J. Sci. Technol. 2019, 4, 97-118. [CrossRef]

51. Yang, L.; Han, D.H.; Lee, B.M.; Hur, J. Characterizing treated wastewaters of different industries using clustered fluorescence EEM-PARAFAC and FT-IR spectroscopy: Implications for downstream impact and source identification. Chemosphere 2015, 127, 222-228. [CrossRef]

52. Kędzierska-Matysek, M.; Matwijczuk, A.; Florek, M.; Barłowska, J.; Wolanciuk, A.; Matwijczuk, A.; Chruściel, E.; Walkowiak, R.; Karcz, D.; Gładyszewska, B. Application of FTIR spectroscopy for analysis of the quality of honey. In BIO Web of Conferences; EDP Sciences: Les Ulis, France, 2018; Volume 10, p. 02008.

53. Asemani, M.; Rabbani, A.R. Detailed FTIR spectroscopy characterization of crude oil extracted asphaltenes: Curve resolve of overlapping bands. J. Pet. Sci. Eng. 2020, 185, 106618. [CrossRef]

54. Xu, R.B.; Yang, X.; Wang, J.; Zhao, H.T.; Lu, W.H.; Cui, J.; Hu, X.L. Chemical composition and antioxidant activities of three polysaccharide fractions from pine cones. Int. J. Mol. Sci. 2012, 13, 14262-14277. [CrossRef] [PubMed]

55. Daoub, R.M.A.; Elmubarak, A.H.; Misran, M.; Hassan, E.A.; Osman, M.E. Characterization and functional properties of some natural Acacia gums. J. Saudi Soc. Agric. Sci. 2018, 17, 241-249. [CrossRef]

56. Lopez-Torrez, L.; Nigen, M.; Williams, P.; Doco, T.; Sanchez, C. Acacia senegal vs. Acacia seyal gums-Part 1: Composition andstructure of hyperbranched plant exudates. Food Hydrocoll. 2015, 51, 41-53. [CrossRef]

57. Lluveras-Tenorio, A.; Mazurek, J.; Restivo, A.; Colombini, M.P.; Bonaduce, I. Analysis of plant gums and saccharide materials. Chem. Cent. J. 2012, 6, 115. [CrossRef] [PubMed]

58. Cermak, P.; Olsovska, J.; Mikyska, A.; Dusek, M.; Kadleckova, Z.; Vanicek, J.; Nyc, O.; Sigler, K.; Bostikova, V.; Bostik, P. Strong antimicrobial activity of xanthohumol and other derivatives from hops (Humulus lupulus L.) on gut anaerobic bacteria. Apmis 2017, 125, 1033-1038. [CrossRef]

59. Bibi, H. Phytochemical analysis and antimicrobial activities of Kochia indica (Wight), plant growing in District Karak Khyber Puhktunkhuwa, Pakistan. Pure Appl. Biol. 2021, 10, 789-796. [CrossRef]

60. Hameed, I.H.; Hussein, H.J.; Kareem, M.A.; Hamad, N.S. Identification of five newly described bioactive chemical compounds in Methanolic extract of Mentha viridis by using gas chromatography-Mass spectrometry (GC-MS). J. Pharmacogn. Phytother. 2015, 7, 107-125.

61. Hatami, S.; Sani, A.M.; Yavarmanesh, M. Chemical composition and antibacterial activity of organic extra virgin olive oil from Iran. Nutr. Food Sci. 2016, 46, 388-395. [CrossRef]

62. Maitra, S.; De, A.; Das, B.; Roy, S.N.; Chakraborty, R.; Samanta, A.; Bhattacharya, S. Seasonal Variation of Phyto-Constituents of Tea Leaves Affects Antiproliferative Potential. J. Am. Coll. Nutr. 2019, 38, 415-423. [CrossRef]

63. Black, H.S.; Boehm, F.; Edge, R.; Truscott, T.G. The benefits and risks of certain dietary carotenoids that exhibit both anti-and pro-oxidative mechanisms-A comprehensive review. Antioxidants 2020, 9, 264. [CrossRef] 
64. Ngamwonglumlert, L.; Devahastin, S.; Chiewchan, N.; Raghavan, V. Plant carotenoids evolution during cultivation, postharvest storage, and food processing: A review. Compr. Rev. Food Sci. Food Saf. 2020, 19, 1561-1604. [CrossRef] [PubMed]

65. Hemaiswarya, S.; Doble, M. Combination of phenylpropanoids with 5-fluorouracil as anti-cancer agents against human cervical cancer (HeLa) cell line. Phytomedicine 2013, 20, 151-158. [CrossRef] [PubMed]

66. Foo, L.W.; Salleh, E.; Hana, S.N. Green Extraction of Antimicrobial Bioactive Compound from Piper Betle Leaves: Probe type Ultrasound-assisted Extraction vs Supercritical Carbon Dioxide Extraction. Chem. Eng. Trans. 2017, 56, 109-114.

67. Lins, C.L.; Block, J.H.; Doerge, R.F. Nitro-para-and meta-substituted 2-phenylindolizines as potential antimicrobial agents. J. Pharm. Sci. 1982, 71, 556-561. [CrossRef]

68. Hema, R.; Kumaravel, S.; Alagusundaram, K. GC/MS determination of bioactive components of Murraya koenigii. J. Am. Sci. 2011, 7, 80-83.

69. Momin, K.; Thomas, S.C. GC-MS analysis of antioxidant compounds present in different extracts of an endemic plant Dillenia scabrella (dilleniaceae) leaves and barks. Int. J. Pharm. Sci. Res. 2020, 11, 2262-2273.

70. Priyanka, C.; Kumar, P.; Bankar, S.P.; Karthik, L. In vitro antibacterial activity and gas chromatography-mass spectroscopy analysis of Acacia karoo and Ziziphus mauritiana extracts. J. Taibah Univ. Sci. 2015, 9, 13-19. [CrossRef]

71. Williams, H.E.; Tokach, M.D.; Dritz, S.S.; Woodworth, J.C.; DeRouchey, J.M.; Nagaraja, T.G.; Goodband, R.D.; Pluske, J.R.; Chitakasempornkul, K.; Bello, N.M.; et al. Effects of chlortetracycline alone or in combination with direct fed microbials on nursery pig growth performance and antimicrobial resistance of fecal Escherichia coli. Anim. Sci. J. 2018, 96, 5166-5178. [CrossRef]

72. Fakhri, S.; Abbaszadeh, F.; Dargahi, L.; Jorjani, M. Astaxanthin: A mechanistic review on its biological activities and health benefits. Pharmacol. Res. 2018, 136, 1-20. [CrossRef]

73. Do Carmo, G.; Fernandes, T.S.; Pedroso, M.; Ferraz, A.; Neto, A.T.; Silva, U.F.; Mostardeiro, M.A.; Back, D.F.; Dalcol, I.I.; Morel, A.F. Phytochemical and antimicrobial study of Pilocarpus pennatifolius Lemaire. Fitoterapia 2018, 131, 1-8. [CrossRef]

74. Wang, D.; Zhu, N.X.; Qin, M.; Wang, Y.Y. Betamethasone suppresses the inflammatory response in LPS-stimulated dental pulp cells through inhibition of NF-kB. Arch. Oral Biol. 2019, 98, 156-163. [CrossRef]

75. Yadav, D.K.; Rai, R.; Kumar, N.; Singh, S.; Misra, S.; Sharma, P.; Shaw, P.; Pérez-Sánchez, H.; Mancera, R.L.; Choi, E.H.; et al. New arylated benzo[h]quinolines induce anti-cancer activity by oxidative stress-mediated DNA damage. Sci. Rep. 2016, 6, 38128. [CrossRef] [PubMed]

76. Prajapati, V.K.; Awasthi, K.; Gautam, S.; Yadav, T.P.; Rai, M.; Srivastava, O.N.; Sundar, S. Targeted killing of Leishmania donovani in vivo and in vitro with amphotericin B attached to functionalized carbon nanotubes. J. Antimicrob. Chemother. 2011, 66, 874-879. [CrossRef]

77. Bellina, F.; Rossi, R. Synthesis and biological activity of pyrrole, pyrroline and pyrrolidine derivatives with two aryl groups on adjacent positions. Tetrahedron 2006, 62, 7213-7256. [CrossRef]

78. Rao, A.V.; Agarwal, S. Role of antioxidant lycopene in cancer and heart disease. J. Am. Coll. Nutr. 2000, 19, 563-569. [CrossRef] [PubMed]

79. Ryu, J.; Kwon, S.J.; Ahn, J.W.; Jo, Y.D.; Kim, S.H.; Jeong, S.W.; Lee, M.K.; Kim, J.B.; Kang, S.Y. Phytochemicals and antioxidant activity in the kenaf plant (Hibiscus cannabinus L.). J. Plant Biotechnol. 2017, 44, 191-202. [CrossRef]

80. Majumder, R.; Dhara, M.; Adhikari, L.; Ghosh, G.; Pattnaik, S. Evaluation of in vitro antibacterial and antioxidant activity of aqueous extracts of Olax psittacorum. Indian J. Pharm. Sci. 2019, 81, 99-109. [CrossRef]

81. Inoue, H.; Maeno, Y.; Iwasa, M.; Matoba, R.; Nagao, M. Screening and determination of benzodiazepines in whole blood using solid-phase extraction and gas chromatography/mass spectrometry. Forensic Sci. Int. 2000, 113, 367-373. [CrossRef]

82. Hsouna, A.B.; Trigui, M.; Mansour, R.B.; Jarraya, R.M.; Damak, M.; Jaoua, S. Chemical composition, cytotoxicity effect and antimicrobial activity of Ceratonia siliqua essential oil with preservative effects against Listeria inoculated in minced beef meat. Int. J. Food Microbiol. 2011, 148, 66-72. [CrossRef]

83. Goel, R.; Luxami, V.; Paul, K. Recent advances in development of imidazo [1, 2-a] pyrazines: Synthesis, reactivity and their biological applications. Org. Biomol. Chem. 2015, 13, 3525-3555. [CrossRef]

84. Kalantarkousheh, S.M.; Hassan, S.A.; Kadir, R.A.; Talib, M.A. Manifestation of existential issues as a brilliant function for quality of matrimony. J. Am. Sci. 2011, 7, 459-465.

85. Varchi, G.; Battaglia, A.; Samorì, C.; Baldelli, E.; Danieli, B.; Fontana, G.; Guerrini, A.; Bombardelli, E. Synthesis of deserpidine from reserpine. J. Nat. Prod. 2005, 68, 1629-1631. [CrossRef]

86. Ubaid, J.M.; Hussein, H.M.; Hameed, I.H. Determination of bioactive chemical composition of Callosobruchus maculutus and investigation of its anti-fungal activity. Int. J. Pharmacogn. Phytochem. Res. 2016, 8, 1293-1299.

87. M’bitsi-Ibouily, G.C.; Marimuthu, T.; Kumar, P.; Choonara, Y.E.; du Toit, L.C.; Pradeep, P.; Modi, G.; Pillay, V. Synthesis, characterisation and in vitro permeation, dissolution and cytotoxic evaluation of ruthenium (ii)-liganded sulpiride and amino alcohol. Sci. Rep. 2019, 9, 4146. [CrossRef]

88. Senhaji, S.; Lamchouri, F.; Toufik, H. Phytochemical content, antibacterial and antioxidant potential of endemic plant anabasis aretioïdes coss. \& moq. (Chenopodiaceae). BioMed Res. Int. 2020, 2020, 6152932.

89. Azahar, N.I.; Mokhtar, N.M.; Arifin, M.A. Piper betle: A review on its bioactive compounds, pharmacological properties, and extraction process. In IOP Conference Series: Materials Science and Engineering; IOP Publishing: Bristol, UK, 2020; Volume 991, p. 012044 . 
90. Liu, D.; Meng, X.; Wu, D.; Qiu, Z.; Luo, H. A natural isoquinoline alkaloid with antitumor activity: Studies of the biological activities of berberine. Front. Pharmacol. 2019, 10. [CrossRef]

91. Kotteswari, M.; Prabhu, K.; Rao, M.R.K.; Mahitha, P.; Balaji, T.K.; Dinakar, S.; Sundaram, R.L. The gas chromatography-mass spectrometry study of one Ayurvedic medicine Ashtachurnam. Drug Invent. Today 2020, 13, 663-667.

92. El-Garawani, I.; Hassab El-Nabi, S.; El Kattan, A.; Sallam, A.; Elballat, S.; Abou-Ghanima, S.; El-Shamy, S. The ameliorative role of Acacia senegal gum against the oxidative stress and genotoxicity induced by the radiographic contrast medium (ioxitalamate) in albino rats. Antioxidants 2021, 10, 221. [CrossRef]

93. Warowicka, A.; Nawrot, R.; Goździcka-Józefiak, A. Antiviral activity of berberine. Arch. Virol. 2020, 165, 1935-1945. [CrossRef]

94. Estolano-Cobián, A.; Noriega-Iribe, E.; Díaz-Rubio, L.; Padrón, J.M.; Brito-Perea, M.; Cornejo-Bravo, J.M.; Córdova-Guerrero, I. Antioxidant, antiproliferative, and acetylcholinesterase inhibition activity of amino alcohol derivatives from 1, 4-naphthoquinone. Med. Chem. Res. 2020, 29, 1986-1999. [CrossRef]

95. Ghani, N.T.A.; Mansour, A.M. Novel palladium (II) and platinum (II) complexes with 1H-benzimidazol-2-ylmethyl-N-(4-bromophenyl)-amine: Structural studies and anticancer activity. Eur. J. Med. Chem. 2012, 47, 399-411. [CrossRef]

96. Al Bratty, M.; Makeen, H.A.; Alhazmi, H.A.; Alhazmi, H.A.; Syame, S.M.; Syame, S.M.; Abdalla, A.N.; Abdalla, A.N.; Homeida, H.E.; Sultana, S.; et al. Phytochemical, Cytotoxic, and Antimicrobial Evaluation of the Fruits of Miswak Plant, Salvadora persica L. J. Chem. 2020, 2020, 4521951. [CrossRef]

97. Hashem, M.A.; Abd-Allah, N.A.; Mahmoud, E.A.; Amer, S.A.; Alkafafy, M. A Preliminary Study on the Effect of Psyllium Husk Ethanolic Extract on Hyperlipidemia, Hyperglycemia, and Oxidative Stress Induced by Triton X-100 Injection in Rats. Biology 2021, 10, 335. [CrossRef]

98. Walter, L.A. Margolis, P. 2-Phenylindolizines. J. Med. Chem. 1967, 10, 498-499. [CrossRef] [PubMed]

99. Andrade, P.B.; Leitão, R.; Seabra, R.M.; Oliveira, M.B.; Ferreira, M.A.3,4-Dimethoxycinnamic acid levels as a tool for differentiation of Coffea canephora var. robusta and Coffea arabica. Food Chem. 1998, 61, 511-514. [CrossRef]

100. Brintha, S.; Renuka, R.; Rajesh, S.; Santhanakrishnan, V.P.; Gnanam, R. Phytochemical analysis and bioactivity prediction of compounds in methanolic extracts of Curculigo orchioides Gaertn. J. Pharmacogn. Phytochem. 2017, 6, $192-197$.

101. Hernández-Ortega, M.; Ortiz-Moreno, A.; Hernández-Navarro, M.D.; Chamorro-Cevallos, G.; Dorantes-Alvarez, L.; NecoecheaMondragón, H. Antioxidant, antinociceptive, and anti-inflammatory effects of carotenoids extracted from dried pepper (Capsicum annuum L.). J. Biomed. Biotechnol. 2012, 2012, 524019. [CrossRef] [PubMed]

102. Chew, B.P.; Park, J.S. Carotenoid action on the immune response. J. Nutr. 2004, 134, 257S-261S. [CrossRef] [PubMed] 